\title{
EFEITOS DA SUPRESSÃO HIIDRICA NOS ASPECTOS PRODUTIVOS E QUALITATIVOS DA CULTURA DO MELÃO
}

\author{
FERNANDO BRAZ TANGERINO HERNANDEZ \\ Engenheiro Agrônomo
}

Orientador: Prof. Dr. JOSÉ ANTONIO FRIZZONE

Tese apresentada à Escola Superior de Agricultura "Luiz de Queiroz", da Universidade de São Paulo, para obtenção do Título de Doutor em Agronomia, Área de Concerração: Irrigação e Drenagen.

PIRACICABA

Estado de São Paulo - Brasil

Setembro - 1995 
Dados internacionais de Catalogação na Publ icação (CIP)

Divisão de Biblioteca e Documentação - CAMPUS "LUIZ DE QUEIROZ"/USP

Hernandez, Fernando Braz Tangerino

Efeitos da supressão hídrica nos aspectos produtivos e qualitativos da cultura do melão. Piracicaba, 1995.

75p. ilus.

Tese - ESALQ

Bibl iografia.

1. Irrigação por gotejamento 2. Me lăo - Produçăo - Efeito do estresse hídrico I. Escola Superior de Agricultura Luiz de Queiroz, Piracicaba

CDD 635.61 


\section{EFEITOS DA SUPRESSÃO HIIDRICA NOS ASPECTOS PRODUTIVOS E QUALITATIVOS DA CULTURA DO MELÃO}

FERNANDO BRAZ TANGERINO HERNANDEZ

Aprovada em 16.10.1995.

Comissão julgadora:

Prof. Dr. José Antonio Frizzone

ESALQ/USP

Prof. Dr. Tarlei Arriel Botrel ESALQ/USP

Prof. Dr. Marcus Vinicius Folegatti

ESALQ/USP

Prof. Dr. Mário Benincasa

CEA/UNESP

Prof. Dr. Marco Eustáquio de Sá

FEIS/UNESP

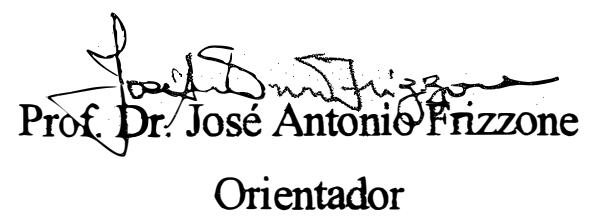


Todos os dias, toda manhã

Sorriso aberto e roup a nova

Passarim preto de terno branco

Pinduca vai esperar o trem

Todos os dias, toda manhã

Ele sozinho na plataforma

Ouve 0 apito, sente a fumaça

$E$ vê chegar 0 amigo trem

Que acontece que nunca parou

Nessa cidade de fim de mundo

E quem viaja pra capital

Não tem olhar para o braço que acenou

$\mathrm{O}$ gesto humano ficou no ar

$\mathrm{O}$ abandono fica maior

E lá na curva desaparece a sua fé

Homem que é homem não perde a esperança não

Ele vai parar

Quem é teimoso não sonha outro sonho não

Qualquer dia ele pára

Assim Pinduca toda manhã

Sorriso aberto e roupa nova

Passarim preto de terno branco.

Vai renovar a sua fé

(Roupa Nova, M. Nascimento e F. Brant) 
Durante mais esta etapa de minha vida profissional Alguns sacrifícios existiram

Mas duas pessoas arcaram com as consequências

Maiores desta etapa: dedicação ao trabalho e ausência À elas

Fernando Henrique Cubo Hernandez e Regina Celi Perez Cubo

DEDICO e OFEREÇO

\section{HOMENAGEM:}

Aos meus pais,

Braz e Edna

cujo comportamento e dedicação

durante a vida, me serviram de

exemplo, inspiração e também motivação profissional. 


\section{AGRADECIMENTOS}

Com algumas pessoas e apoio financeiro de Instituições, seguramente tive a oportunidade de aprender novas palavras e tornar outras ainda mais belas. Meu reconhecimento e gratidão.

À FAPESP (Fundação de Amparo à Pesquisa do Estado de São Paulo) pelo suporte financeiro para a realização deste trabalho.

À Escola Superior de Agricultura 'Luiz de Queiroz", através do Departamento de Engenharia Rural, pela acolhida e apoio.

Ao CAPES, pela bolsa de estudo concedida.

Ao Prof. Dr. José Antonio Frizzone, orientador e amigo, exemplo de profissionalismo e dedicação ao ensino, pela oportunidade de convivência.

Aos meus orientados: Marcelo Akira Suzuki, Marco Antônio Franco Lemos Filho, Milton Akira Yokota, Mauro Koji Kobayashi, Nelson Eidi Chidi e João Antônio Donizeti Bedum, pelo entusiasmo, dedicação e convivência.

Aos colegas de trabalho na FEIS-UNESP, Edson Lazarini, João Luis

Zocoler, Maria Aparecida Anselmo Tarsitano, Marco Eustáquio de Sá, Orivaldo Arf e Salatiér Buzetti, pela satisfação do trabalho conjunto. 
Ao pessoal de apoio na FEIS-UNESP, Valéria Alves Paiva, Emídio Lima e Durvalino Cândido de Souza, pela dedicação e amizade.

Aos colegas de curso, Lázaro Nonato, Marcelo Targa, Vital Pedro da Silva Paz e Sérgio Marques Júnior pelo convívio sempre agradável.

À Ipiranga Serrana Fertilizantes S.A, nas pessoas dos Engenheiros Agrônomos Sérgio Tadeu Decaro e Riolando A. G. Cozzo, por terem cedido os fertilizantes utilizados no presente experimento.

Aos demais professores, colegas e funcionários do curso, pelo apoio, amizade e sugestões recebidas.

$\grave{A}$ todas as pessoas que direta ou indiretamente contribuíram para a minha formação profissional e pessoal. 


\section{SUMÁRIO}

PÁGINA

LISTA DE FIGURAS

LISTA DE QUADROS

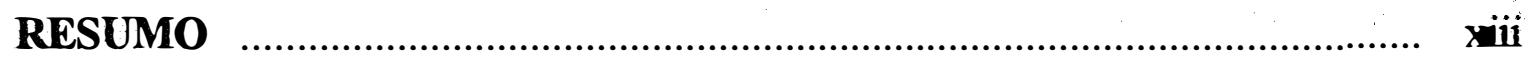

SUMMARY

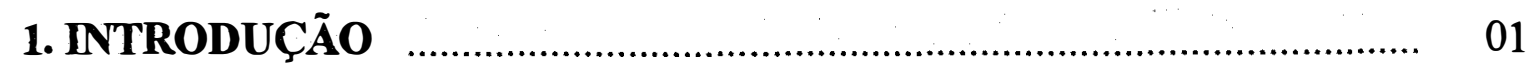

2. REVISÃO DE LITERATURA ……..................................................... 05

2.1. Aspectos gerais da cultura do melão e qualidade de frutos $\quad$..................... 05

2.2. Necessidades hídricas, inigação e produtividade $\quad$.................................. 07

3. MATERIAL E MÉTODOS …........................................................ 14

3.1. Localização do experimento …............................................................... 14

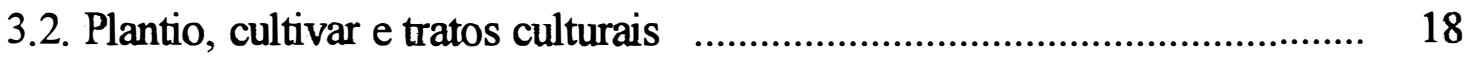

3.3. Simulador de Veranico ......................................................................... 19

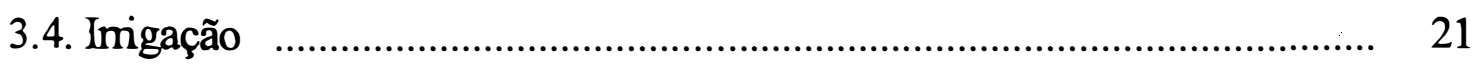

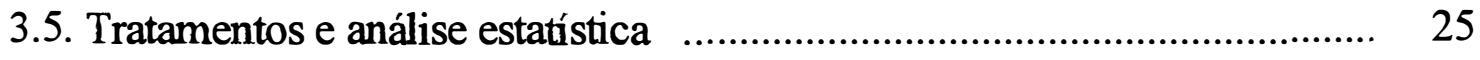

3.6. Parâmetros avaliados $\quad$.............................................................................. 27

3.7. Custo de produção .................................................................................. 31

4. RESULTADOS E DISCUSSÃO …..................................................... 33

4.1. Desenvolvimento da cultura ….............................................................. 33

4.2. Aspectos produtivos .................................................................. 37

4.3. Aspectos qualitativos ...................................................................... 44

4.4. Potencial matricial da água do solo e umidade ........................................ 46 


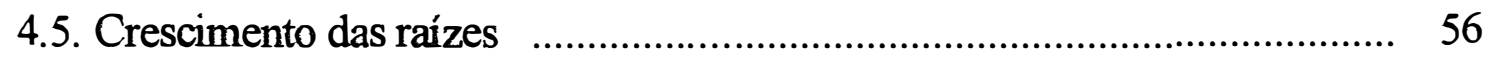

4.6. Custo de produção

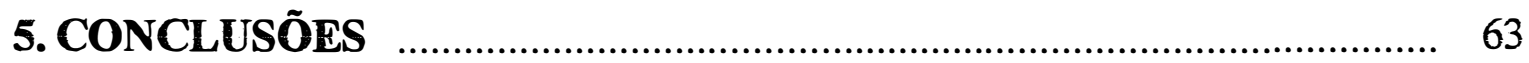

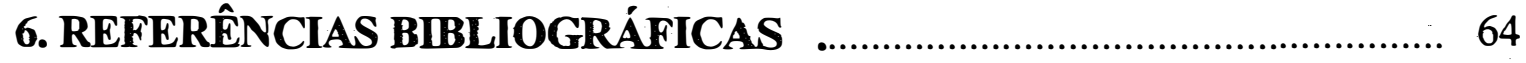

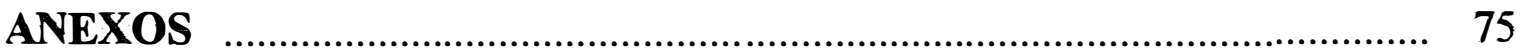




\section{LISTA DE FIGURAS}

FIGURA

PÁGINA

1 Curva característica de retenção de água no solo, ajustada segundo GENUCHTEN (1980)

2 Representação esquemática dos coeficientes de cultivo utilizado durante o experimento

3 Evapotranspiração cultural ( $\mathrm{mm} / \mathrm{dia})$ estimada pelo Tanque Classe A durante o experimento

4 Volume de água aplicado (litros/planta) durante o experimento no Tratamento 7 (testemunha) 25

5 Fator de cobertura do solo observado para os diferentes tratamentos

6 Relações entre produtividade atual e produtividade máxima $\left(Y_{a} / Y_{\text {max }}\right)$ obtidas em função dos tratamentos empregados .

7 Módulo do potencial matricial (a) e \% da CAD (b) ocomidos no Tratamento 1

8 Módulo do potencial matricial (a) e \% da CAD (b) ocorridos no Tratamento 2

9 Módulo do potencial matricial (a) e \% da CAD (b) ocorridos no Tratamento 3 
10 Módulo do potencial matricial (a) e \% da CAD (b) ocomidos no Tratamento 4

11 Módulo do potencial matricial (a) e \% da CAD (b) ocomidos no Tratamento 5

12 Módulo do potencial matricial (a) e \% da CAD (b) ocomidos no Tratamento 6

13 Módulo do potencial matricial (a) e \% da CAD (b) ocorridos no Tratamento 7

14 Módulo do potencial matricial (a) e \% da CAD (b) ocomidos no Tratamento 8 


\section{LISTA DE QUADROS}

QUADRO

PÁGINA

1 Análise química do solo

2 Análise granulométrica do solo

3 Potencial matricial versus umidade gravimétrica e densidade do solo para as diferentes profundidades

4 Parâmetros de GENUCHTEN (1980) obtidos para o solo e utilizados na aplicação do modelo

5 Potencial matricial mínimo, dias após a semeadura (D.A.S.), período e número de dias (N.D.) de restrição hídrica

6 Números de dias de cada estágio fenológico e ciclo total da cultura nos diferentes tratamentos

7 Resultados obtidos na análise de variância preliminar, valores de F, teste de Tukey, médias e valores percentuais obtidos para os parâmetros produtivos da cultura de melão

8 Parâmetros produtivos para frutos de melão em cada colheita .

9 Resultados obtidos na análise de variância preliminar, teste $\mathrm{F}$, teste de Tukey e médias obtidas para os parâmetros qualitativos dos frutos de melão colhidos em novembro de 1994, em Ilha Solteira, SP 
10 Distribuição percentual das raízes do meloeiro em condições de irrigação por gotejamento

11 Estimativa de custo de produção e receita em um hectare de melão, cv. Valenciano Amarelo, na região de llha Solteira, SP. Dados relativos ao Tratamento 7 (testemunha)

12 Análise comparativa do consumo de água, energia e análise econômica da produção de um hectare de melão 


\section{EFEITOS DA SUPRESSÃO HÍDRICA NOS ASPECTOS PRODUTIVOS E QUALITATIVOS DA CULTURA DO MELĀO}

\section{Autor: FERNANDO BRAZ TANGERINO HERNANDEZ \\ Orientador: Prof. Dr. JOSÉ ANTONIO FRIZZONE}

\section{R E S U M O}

A cultura do melão tem se firmado no Brasil como importante fonte de divisas para o agricultor e agricultura, ocupando inclusive uma parcela expressiva na nossa pauta de exportações. No entanto, muitos fatores relacionados ao suprimento hídrico carecem ainda de estudos mais detalhados. Assim, pretendeu-se com esse trabalho definir e quantificar os efeitos do déficit hídrico sobre os aspectos produtivos e qualitativos nas diferentes fases fenológicas da cultura, utilizando-se o potencial matricial da água no solo como parâmetro de controle. Essa definição e quantificação assume particular importância do ponto de vista de planejamento da atividade agrícola. Para tanto, conduziu-se a cultura do melão sob irrigação por gotejamento e para cada fase fenológica foram utilizados os potenciais matriciais de água no solo de aproximadamente $-40 \mathrm{kPa}$ e $-80 \mathrm{kPa}$ como críticos. Os resultados mostraram que o período de déficit hídrico que causa maiores decréscimos na produtividade é o da frutificação e florescimento. Sob condições de irigação por gotejamento, durante a 
fase inicial da cultura, o solo é mantido em umidades bastante próximas da saturação, enquanto que na fase de frutificação, mesmo com irrigação diária, chega-se a ser consumido até $60 \%$ da $\mathrm{CAD}$. A maior produtividade foi obtida com a supressão hídrica na fase vegetativa da cultura e foi de $30.761 \mathrm{~kg} / \mathrm{ha}$, proporcionando uma renda líquida de US\$23.683,45 por hectare. 


\title{
EFFECTS OF WATER DEFICIT ON THE PRODUCTIVITY AND QUALITY OF MUSKMELON
}

\author{
Author: FERNANDO BRAZ TANGERINO HERNANDEZ \\ Adviser: Prof. Dr. JOSÉ ANTONIO FRIZzONE
}

\section{SUMMARY}

The muskmelon crop represent an important contribution for the total Brazilian exportation products. Therefore, many factors related to the water supply needs more accurate studies. In this research was evaluated the effect of water deficit on the productivity and quality of muskmelon during the different phenological stages. The matric potential $\left(\psi_{\mathrm{m}}\right)$ was used as a control parameter. The experiment was carried out at Faculdade de Engenharia de Itha Solteira, Universidade Estadual Paulista (UNESP). The drip irrigation system was used and the critical $\psi_{\mathrm{m}}$ adopted were $-40 \mathrm{kPa}$ and $-80 \mathrm{kPa}$. The soil moisture was kept close to field capacity at the initial crop stage. At the frutification state, even with daily irrigation, about $60 \%$ of the available water storage was depleted by the 
crop. The results showed that the water deficit during the frutification stage reduced on about $24 \%$ the fruits yields. The applied $\psi_{\mathrm{m}}$ of $-80 \mathrm{kPa}$ in the initial stage resulted in a yield of $30,761 \mathrm{~kg} \mathrm{ha}^{-1}$ that represented a net income of US\$ 23,683.45 per hectare. 


\section{INTRODUÇĀO}

A produção agrícola tem na inigação um poderoso instrumento para viabilizar a agricultura em determinadas regiões, especialmente as áridas e semiáridas. A tentativa de se estabelecer estimativas de produção cada vez mais confiáveis a partir dos recursos disponíveis (principalmente água e nutrientes), vem sendo objeto de estudos nos últimos anos de diversos autores, tais como BARRET e SKOGERBOE (1980), HART et al (1980), FRIZZONE (1986), BATTIKHI e HILL (1988), ISLAM et al (1989), RADULOVICH (1990) e FRIZZONI (1995).

O melão (Cucumis melo L.) é uma planta da família Cucurbitaceae e segundo MELO et al (1995), originária da África ou Índia, ocupando importante lugar na olericultura brasileira e, nos últimos anos, também em nossa pauta de exportações agrícola.

A introdução no Brasil foi feita pelos europeus no Estado do Rio Grande do Sul, seu maior produtor até 1966. Depois seu cultivo espalhou-se por todo o Brasil, como o sul do Pará, nordeste brasileiro e sudoeste do Estado de São Paulo. Segundo a EMBRAPA (1989), a área de produção nas regiões sudeste e nordeste no ano de 1986 foi de 387 e 3.370 hectares, respectivamente, e a produtividade média neste mesmo 
ano foi de 12,2 tha para a região sudeste contra 6,4 tha para a região nordeste. $A$ CODEVASF (1989) relata que, são várias as empresas, atualmente no ramo da produção de melão para exportação, envolvendo milhares de hectares cultivados, tendendo a aumentar a cada ano, dado a grande demanda do mercado norte americano e o europeu.

A discrepante produtividade entre regiões relatada acima deve-se a vários fatores, principalmente ao manejo inadequado dado à cultura. Neste aspecto, o suprimento hídrico, na maioria das vezes, é feito de maneira descontrolada, não havendo racionalidade na sua prática. Neste caso, pode-se ter uma dotação hídrica abaixo ou acima do exigido pela cultura.

Apesar da região nordeste ser, em área, o grande produtor, o consumo maior dos frutos do meloeiro é feito na região sudeste, obrigando a exportação para os centros consumidores desta região, acarretando um enorme aumento no preço final do produto ao consumidor. Com a abertura do mercado extemo, o melão passou de artigo importado para artigo de exportação.

O aroma, o sabor e a aparência dos frutos de melão são fatores deterninantes da sua qualidade, e, portanto, definitivos para uma boa comercialização. Nesse sentido, um dos pontos-chave para uma boa produtividade e qualidade dos frutos reside no adequado suprimento hídrico, no qual deve-se levar em consideração a fenologia da cultura, disponibilidade de água e seu manejo. 
Em condições de abundância de água e energia de baixo custo, a produção máxima de uma cultura geralmente é muito próxima da produção econômica. Quando a água e energia são escassas e/ou dispendiosas, considerações econômicas devem ser incluídas nas decisões de manejo da irrigação. Neste caso, a quantificação do efeito do manejo da inrigação sobre a produção da cultura é necessária para subsidiar tal decisão (MARTIN et al, 1984). O conceito de irrigação com déficit como estratégia de maximização de receita vem sendo discutido recentemente por vários pesquisadores, tais como HAGAN e STEWART (1972), STEWART e HAGAN (1973), PALACIOS (1981), RAO et al (1988), ENGLISH (1990) e ENGLISH et al (1990).

Porém, não são apenas os aspectos econômicos que vêm preocupando a agricultura, mas a economia de água traz poupança de energia e também pode evitar, amenizar ou até postergar o aparecimento de patógenos de solo, que muitos prejuízos trazem à agricultura, muitas vezes até inviabilizando o plantio.

Este trabalho considera como hipótese fundamental a exigência diferenciada de água ao longo do ciclo da cultura do melão e que diferentes rendimentos estão associados a diferentes níveis de potencial matricial de água no solo, como resultado de alterações que se produzem sobre o desenvolvimento da planta, bem como sobre a sensibilidade desigual ao déficit hídrico de cada etapa do ciclo fenológico.

Assim, o presente trabalho teve por objetivo a definição e quantificação da sensibilidade das diferentes fases fenológicas da cultura do melão ao déficit hídrico, 
visando subsidiar a elaboração de programas de racionalização do uso da água (em regiões produtoras onde esse recurso é escasso) ou ainda subsidiar elaboração de programas de simulação de plantios, para regiões chuvosas, porém sujeitas à veranicos freqüentes. 


\section{REVISÃO DE LITERATURA}

\subsection{Aspectos gerais da cultura do melão e qualidade de frutos}

O meloeiro (Cucumis melo L.) é uma hortaliça da familia Cucurbitaceae, cujos frutos tem excelente aspecto, sabor e aroma, constituindo numa fina iguaria (FILGUEIRA, 1981). Ainda sobre o meloeiro, GOMES (1977) informa que é uma planta anual, herbácea, prostrada, de hastes trepadoras e folhas pecioladas, grandes, aveludadas, com três a cinco lóbos e flores amarelas. Os frutos são bagas, grandes, polimorfes, pubescentes ou glabos, de cores variadas. Segundo BERNARDI (1974), o melão é uma espécie considerada como derivada das formas selvagens, originária dos continentes asiático e africano. Para muitos, a Índia foi seu centro de origem.

Os frutos do meloeiro sofrem variações no tamanho, forma, cor e peso. A casca pode ser lisa, enrugada tipo "rede" ou em forma de costelas. Os frutos imaturos geralmente são verdes e quando maduros podem permanecer verdes ou mudarem para amarelo ou castanho avermelhado, dependendo do cultivar (VIEIRA, 1984).

As plantas de melão se desenvolvem bem em climas quentes com temperatura de 18 a $25^{\circ} \mathrm{C}$. No entanto as sementes germinam melhor quando o solo 
apresenta uma temperatura entre 21 e $31^{\circ} \mathrm{C}$. A temperatura é um importante fator na deiscência de pólen das cucurbitáceas, sendo que as plantas de melão requerem temperaturas moderadamente elevadas. Estabeleceu-se que as temperaturas mínimas para que ocorram anteses e deiscência em melão é de $18,3^{\circ} \mathrm{C}$ com um ótimo entre 20 e $21^{\circ} \mathrm{C}$ e até $23,9^{\circ} \mathrm{C}$. Frutos de melão colhidos e mantidos em altas temperaturas (de 29,4 a $32,1^{\circ}$ C) rapidamente maturam e ocorre perda do conteúdo de açúcar, diminuindo seu valor comercial. Entretanto, em temperaturas de $-1,1$ a $4,4^{\circ} \mathrm{C}$ reduzem sua classe de amadurecimento e perdas de açúcar, aumentando notavelmente a qualidade e resistência ao transporte (FUENTES, 1988).

ERMLAND Jr. (1986) relata que as características de qualidade e de desenvolvimento obtidos com um cultivar pode variar de uma região para outra. Já COSTA (1987) relata que o acúmulo de açúcares durante o desenvolvimento dos frutos é de grande interesse porque há forte correlação entre o conteúdo de açúcares e a qualidade dos frutos. Para VIEIRA (1984), a qualidade dos melões está altamente correlacionada com o conteúdo de açúcares. Por isso um fruto realmente bom deve apresentar um sabor característico, que é função dos compostos orgânicos produzidos durante o amadurecimento. Alguns desses compostos foram identificados recentemente e muitos deles são alcoóis e ésteres de ácidos.

Segundo COSTA (1987), a condição de cultivo do meloeiro constitui fator de grande influência na qualidade dos frutos. A coloração e as características organolépticas são dependentes da adubação, do solo, do clima e da disponibilidade 
hídrica, da mesma forma como o tamanho dos frutos está amplamente relacionado à produtividade da planta, dada a limitação da área foliar por fruto, o que melhora a qualidade dos frutos e conseqüentemente seu valor comercial, como também sua resistência ao transporte e armazenamento.

\subsection{Necessidades hídricas, irrigação e produtividade}

Muitos são os trabalhos encontrados na literatura que tratam dos aspectos relacionados à salinidade e seus efeitos sobre a cultura do melão, como os de MIZRAHI e PASTERNAK (1985), GRATTAN et al (1987), MENDLINGER e PASTERNAK (1992a), MENDLINGER e PASTERNAK (1992b), MENDLINGER e FOSSEN (1993) e MENDLINGER (1994), entre outros. A leitura destes trabajhos indica a imigação por gotejamento como forma de produção desta hortaliças em condições de salinidade. A preocupação de muitos autores com este tema tem justificativa no fato de que grandes áreas de produção desta cultura estão em regiões sujeitas aos efeitos da salinidade. Já, o efeito do déficit hídrico sob a cultura não tem recebido a devida atenção por parte dos pesquisadores.

Com relação às necessidades hídricas, o meloeiro apresenta, segundo FERREIRA (1982), peculiaridades na exigência em água Durante a germinação e emergência requer umidade moderada no solo. No período de desenvolvimento das três ramas laterais, na floração e início da frutificação, tem-se as fases de maior exigência de água, nos quais recomendam-se irrigações mais freqüentes. Após isso, 
tem-se a fase de crescimento dos frutos, em que a freqüência de irrigação deve ser diminuída. Durante a maturação, um excesso de água exerce uma influência decisiva na qualidade dos frutos, afetando negativamente o seu sabor e a sua capacidade de conservação, além de favorecer aos patógenos, devendo com isso diminuir gradativamente as aplicações de água ao iniciar-se a fase final de maturação dos frutos.

COELHO et al (1977), estudando a influência dos métodos de irrigação por sulco e por gotejo na cultura do melão, observaram uma superioridade, embora pequena, do método de gotejamento sobre o método de imigação por sulcos, por promover um desenvolvimento mais rápido da planta. Contudo, a taxa de acumulação diária de matéria seca foi significativamente igual nos dois métodos.

GOLDBERG et al (1976) comentam o efeito no crescimento vegetativo da cultura do melão irrigado por gotejamento, em comparação com outros métodos, mostrando que, nas parcelas irrigadas por gotejo, a colheita foi realizada duas semanas antes das irrigadas por aspersão e uma semana antes da irrigada por sulco.

A literatura não deixa dúvidas quanto à eficiência da irrigação localizada combinada com a fertirnigação, promovendo a melhoria da eficiência do uso dos fertilizantes, reduzindo perdas dos nutrientes por lixiviação, condicionando à um melhor controle da concentração de nutrientes no solo e economizando mão-de-obra e energia (BRESLER, 1977; MEDINA SAN JUAN, 1985; PIZARRO, 1990). 
MACGLLIVRAI (1951), conduzindo experimento de irrigação em melão Cantaloupe na Califórnia (EUA), molhando o solo até a capacidade de campo à profundidade de $30 \mathrm{~cm}$, observou que a irrigação não afetou o crescimento de raiz em profundidade e que o tamanho de frutos e total de sólidos solúveis não foram extremamente afetados, sendo que os rendimentos foram sensivelmente aumentados. O autor cita ainda que os máximos rendimentos foram obtidos com a aplicação de 150 a $250 \mathrm{~mm}$ de água durante o ciclo.

O método de irrigação por gotejamento, empregado na condução da cultura do melão, variedade Valenciano Amarelo CAC, no Vale do São Francisco, proporcionou maior peso médio de frutos $(0,911 \mathrm{~kg} /$ fruto), maior número de frutos colhidos por unidade de área (12.915 frutos ha) e, conseqüentemente, maior produção (média de $11.846 \mathrm{~kg} / \mathrm{ha}$ ) quando comparado com o método de irrigação por sulco (médias de 0,660 kg/fruto, 11.549 frutos/ha e $7.941 \mathrm{~kg} / \mathrm{ha}$, respectivamente), segundo ABREU et al, (1978).

DAN (1974) conduzindo em Israel experimento para determinar os parâmetros de irrigação e fertilização da cultura do melão irrigado por gotejo, com vista a obtenção de uma produção ótima mostrou que o nível de irrigação não teve influência marcante na produção total (foram testados os fatores do Tanque Classe A de $0,55,0,70,0,85$, e 1,00 ). Houve tendência para uma produção maior com menores quantidades de água aplicada. Com relação aos diversos intervalos testadas (6, 24, 96 e 192 horas), também não foram encontradas diferenças significativas. 
SHMUELI e GOLDBERG (1971) realizaram um estudo comparativo entre os métodos de irrigação por sulco, aspersão e gotejo, na cultura do melão, observando um desenvolvimento vegetativo mais rápido e uma maior produção com o método de gotejo, não tendo sido detectadas diferenças significativas na produção entre os métodos de sulco e aspersão.

Em trabalho realizado em Petrolina - PE, COELHO et al (1977) compararam os métodos de imigação por sulco e gotejamento em diversas condições de manejo, na cultura do melão Valenciano Amarelo. Os resultados mostraram que as melhores produções de melão foram obtidas com o gotejamento na freqüência de dois dias, utilizando os fatores de 0,75 e 1,00 de evaporação do Tanque Classe A Neste caso as produções não diferiram daquelas obtidas pelo método de sulco. Observou-se ainda que as produções no método de sulco não foram significativamente afetadas pela freqüência de irrigação.

OLITTA et al (1978), comparando os métodos de irrigação por sulco e gotejamento na cultura do melão variedade Valenciano Amarelo, verificaram uma produção média de 7.941 e $11.846 \mathrm{~kg} / \mathrm{ha}$, respectivamente para as imigações por sulco e gotejamento. Este fato pode ser atribuído em parte ao maior número de frutos, bem como ao maior tamanho dos frutos colhidos do tratamento com gotejamento.

Com relação à eficiência do uso da água (e.u.a.), muitas vezes, esta e a resistência à seca são frequentemente tratadas como sinônimos, embora elas normalmente não estão relacionadas (HSIAO, 1973 e BEGG e TURNER, 1976). A 
e.u.a. refere-se à um parâmetro de rendimento, total da colheita por unidade de água utilizada e o maior objetivo das pesquisas nesta área está em conseguir altos valores de e.u.a., mantendo-se altas produtividades. No entanto, a ênfase dada à resistência à seca é frequentemente relacionada à sobrevivência da planta durante períodos de déficit hídrico, resultante do baixo fomececimento de água e alta radiação, temperatura e demanda evaporativa da atmosfera.

Dessa maneira, tanto a produtividade biológica ou a de frutos e a quantidade evapotranspirada, são dependentes do balanço de energia e a eficiência do uso da água por sua vez, é dependente da distribuição de energia dentro da cultura.

Em estudo do momento de se cessar a imigação, RITSCHEL et al (1994) não encontraram diferenças estatisticamente significativas para a produtividade quando a imigação foi cessada aos 56, 63 e 70 dias. No entanto na melhor conversão água matéria (e.u.a.), este valor ficou em 19,82 kilos por metro cúbico de água aplicado.

De acordo com KRAMER (1969), o estresse hídrico sofrido pelas plantas, altera o seu desenvolvimento, modificando sua fisiologia, morfologia e principalmente, afetando as reações bioquímicas a nível celular. No entanto, segundo FILGUEIRA (1981), o meloeiro não é uma planta especialmente exigente em água devido à sua origem em região de clima desértico. $\mathrm{O}$ autor cita ainda que durante a primeira fase de desenvolvimento, inclusive germinação e emergência, requer umidade moderada no solo. Durante o período de desenvolvimento das ramas laterais, na floração e início da frutificação, recomendam-se imigações mais freqüentes, sendo 
esta a fase de maior exigência em água Após isso, durante o crescimento dos frutos e início da maturação, diminuiem-se as aplicações de água, mantendo-se o solo quase seco antes da colheita.

PHENE et al (1987) estudaram o comportamento da cultura do melão frente à frequência de irrigação e gotejamento em superficie e subsuperficie. O estudo se deu em condições de lisímetro e mostrou para um ciclo de 97 dias, um consumo de 499 mm. Já a estimativa da evapotranspiração cultural variou entre 403 e 490 mm, em função dos tratamentos empregados.

MILLAR (1984) mostra que para obter rendimentos perto do nível potencial da cultura é necessário alta frequência de irrigação e um potencial matricial de manejo em torno de $-50 \mathrm{kPa}$. Considera dois dias como turno de rega ideal para a cultura. Já DOORENBOS e PRUTTT (1976), considera que o potencial matricial de água no solo na faixa entre -30 e $-81 \mathrm{kPa}$ é o ideal para a obtenção de máximas produtividades. Considera ainda o período entre a floração e a colheita como sendo o crítico à cultura, em relação ao suprimento hídrico.

CALEGAR e COELHO (1987) procederam a uma análise econômica da irnigação: por sulco e gotejamento em diversas condições de manejo na cultura do melão, variedade Valenciano Amarelo. Economicamente, os melhores resultados foram obtidos com irrigação por gotejo, cerca de $55 \%$ de aumento na renda líquida, quando comparados com os resultados do método de irrigação por sulco. As 
principais restrições apresentadas pelos autores referem-se ao alto investimento inicial e à falta de estudos da flexibilidade dos equipamentos de irrigação por gotejo.

Em relação à flexibilidade dos equipamentos de irrigação por gotejamento para a utilização em outras culturas, trabalhos realizados por BEDUM et al (1994) e BEDUM (1995) mostram ser possível a rotação melão-milho, com apenas adaptações no esquema de plantio da cultura do milho. 


\section{MATERIAL E MÉTODOS}

\subsection{Localização do experimento}

O experimento foi instalado na Área Experimental de Agricultura Irrigada da Fazenda de Ensino e Pesquisa da Faculdade de Engenharia - Campus de Ilha Solteira - UNESP, localizada em Ilha Solteira, Estado de São Paulo, no encontro aproximado das coordenadas geográficas $20^{\circ} 22^{\prime}$ de Latitude Sul e $51^{\circ} 22^{\prime}$ de Longitude Oeste, com altitude média de 335 metros. O clima é do tipo Aw, segundo a classificação de Köeppen, apresentando temperatura média anual de $24,5^{\circ} \mathrm{C}$, precipitação pluviométrica anual de $1.232 \mathrm{~mm}$ e uma umidade relativa média de $64,8 \%$ (HERNANDEZ et al, 1995).

O solo da área foi classificado como Podzólico Vermelho Escuro, eutrófico, textura arenosa, segundo CARVALHO e MELLO (1989). As análises, química, fisica e fisico-hídrica do solo da área experimental estão expressas nos Quadros 1 e 2 e 3 e a curva característica de retenção de água no solo está ilustrada na Figura 1.

Para o ajuste da curva característica de retenção de água no solo foi utilizado o modelo proposto por GENUCHTEN (1980). Segundo este modelo, $\alpha$, m e n são 
parâmetros de solo, enquanto que $\theta_{R}$ e $\theta_{S}$ são respectivamente a umidade volumétrica $\left(\mathrm{cm}^{3} . \mathrm{cm}^{-3}\right)$ residual e de saturação. Os valores dos coeficientes utilizados estão apresentados no Quadro 4.

QUADRO 1 - Análise química do solo.

\begin{tabular}{c|c|c|c|c|c|c|c|c}
\hline \hline $\mathbf{P}$ & Mo. & $\mathbf{K}$ & $\mathbf{C a}$ & $\mathbf{M g}$ & $\mathbf{H}+\mathbf{A l}$ & $\mathbf{S}$ & $\mathbf{C T C}$ & $\mathbf{V}$ \\
\hline $\mathrm{ppm}$ & $\%$ & \multicolumn{6}{|c}{$\mathrm{meq} / 100 \mathrm{~cm}^{3}$} & \\
\hline 18 & 1,5 & 0,12 & 2,4 & 0,6 & 1,5 & 3,12 & 4,6 & 67,8 \\
\hline \hline
\end{tabular}

QUADRO 2 - Análise granulométrica do solo.

\begin{tabular}{c|c|c|c|c}
\hline \hline $\begin{array}{c}\text { PROFUNDIDADE } \\
\mathbf{c m}\end{array}$ & $\begin{array}{c}\text { AREIA TOTAL } \\
\%\end{array}$ & $\begin{array}{c}\text { ARGILA } \\
\%\end{array}$ & $\begin{array}{c}\text { SILTE } \\
\%\end{array}$ & $\begin{array}{c}\text { CLASSIFI- } \\
\text { CAÇ̃o }\end{array}$ \\
\hline $00-15$ & 85,5 & 10,5 & 4,0 & Arenosa \\
\hline $15-30$ & 84,5 & 11,0 & 4,5 & Arenosa \\
\hline $30-45$ & 82,0 & 14,5 & 3,5 & Arenosa \\
\hline $45-60$ & 80,5 & 17,5 & 2,0 & Arenosa \\
\hline $60-75$ & 78,5 & 17,5 & 4,0 & Arenosa \\
\hline \hline
\end{tabular}

QUADRO 3 - Potencial matricial versus umidade gravimétrica e densidade do solo para as diferentes profundidades.

\begin{tabular}{|c|c|c|c|c|c|c|c|c|c|c|}
\hline \multirow[t]{2}{*}{$\begin{array}{l}\text { Profun- } \\
\text { didade }\end{array}$} & \multicolumn{9}{|c|}{$\begin{array}{c}\text { Potencial matricial } \\
\text { centímetros de coluna de água (cca) }\end{array}$} & \multirow{2}{*}{$\begin{array}{c}\mathbf{D g}^{*} \\
\text { g.cm }\end{array}$} \\
\hline & -0 & -10 & -40 & -100 & $-\mathbf{3 0 0}$ & -500 & -1000 & $-\mathbf{5 0 0 0}$ & -15000 & \\
\hline \multicolumn{11}{|c|}{ Umidade gravimétrica $\left(\mathrm{g}_{\mathrm{g}} \mathrm{g}^{-1}\right)$} \\
\hline $10 \mathrm{~cm}$ & 0,2900 & 0,2564 & 0,1809 & 0,1277 & 0,1074 & 0,1023 & 0,1019 & 0,0554 & 0,0460 & 1,6 \\
\hline $20 \mathrm{~cm}$ & 0,1825 & 0,1656 & 0,1579 & 0,1268 & 0,1054 & 0,0857 & 0,0857 & 0,0668 & 0,0660 & 1,8 \\
\hline $30 \mathrm{~cm}$ & 0,1661 & 0,1501 & 0,1377 & 0,1078 & 0,0887 & 0,0814 & 0,0778 & 0,0492 & 0,0467 & 1,9 \\
\hline
\end{tabular}

* Densidade global 
A expressão matemática do modelo de GENUCHTEN (1980) que faz a transformação do potencial matricial lido nos tensiômetros em umidade volumétrica está expressa a seguir:

$$
\theta a=\theta r+\frac{\theta s-\theta r}{\left[1+(\alpha|\psi m|)^{n}\right]^{m}}
$$

onde: $\quad \theta_{\mathrm{a}}=$ umidade atual $\left(\mathrm{cm}^{3} \cdot \mathrm{cm}^{-3}\right)$;

$\theta_{\mathrm{r}}=$ umidade residual $\left(\mathrm{cm}^{3} \cdot \mathrm{cm}^{-3}\right)$;

$\theta \mathrm{s}=$ umidade de saturação $\left(\mathrm{cm}^{3} \cdot \mathrm{cm}^{-3}\right)$;

$\Psi_{\mathrm{m}}=$ potencial matricial (cca);

$\alpha, \mathrm{m}$ e $\mathrm{n}=$ coeficientes gerados pelo modelo.

QUADRO 4 - Parâmetros de GENUCHTEN (1980) obtidos para o solo e utilizados na aplicação do modelo.

\begin{tabular}{cccc}
\hline PARÂMETROS & $\mathbf{1 5} \mathbf{~ c m}$ & PROFUNDIDADE & $\mathbf{4 5} \mathbf{~ c m}$ \\
\hline$\alpha(1 / \mathrm{cm})$ & 0,060271 & $\mathbf{3 0} \mathbf{~ c m}$ & 0,037687 \\
$\mathrm{~m}$ & 0,330235 & 0,037687 & 0,288209 \\
$\mathrm{n}$ & 1,385448 & 0,288209 & 1,546568 \\
$\theta_{\mathrm{R}}\left(\mathrm{cm}^{3} \cdot \mathrm{cm}^{-3}\right)$ & 0,097 & 1,546568 & 0,089 \\
$\theta_{\mathrm{S}}\left(\mathrm{cm}^{3} \cdot \mathrm{cm}^{-3}\right)$ & 0,396 & 0,089 & 0,316 \\
$\theta_{\mathrm{PMP}}\left(\mathrm{cm}^{3} \cdot \mathrm{cm}^{-3}\right)$ & 0,097 & 0,316 & 0,089 \\
$\theta_{\mathrm{CC}}\left(\mathrm{cm}^{3} \cdot \mathrm{cm}^{-3}\right)$ & 0,255 & 0,089 & 0,236 \\
$\mathrm{C} \cdot \mathrm{A}$. & 0,991 & 0,236 & 0,980 \\
CAD $(\mathrm{mm})$ & 23,7 & 0,980 & 66,2 \\
\hline PESR $(\mathrm{mm})$ & 150 & 44,1 & 450 \\
\hline C.A. & & 300 & \\
\hline
\end{tabular}

C.A. : coeficiente de ajuste

$\theta_{\mathrm{R}}=\theta_{\mathrm{PMP}}$

$\mathrm{PESR}=$ profundidade efetiva do sistema radicular 
A umidade foi considerada na capacidade de campo quando a curva característica de água no solo apresentou uma correspondência a $-5,89 \mathrm{kPa}(-60 \mathrm{cca})$.

Para os tensiômetros instalados à 15 centímetros foram considerados os parâmetros gerados pelo modelo a partir dos valores de umidade volumétrica média e potencial matricial nas amostragens de 10 e 20 centímetros de profundidade. Para os tensiômetros instalados nas profundidades de 30 e 45 centímetros foram considerados os parâmetros gerados para a pronfundidade de 30 centímetros.

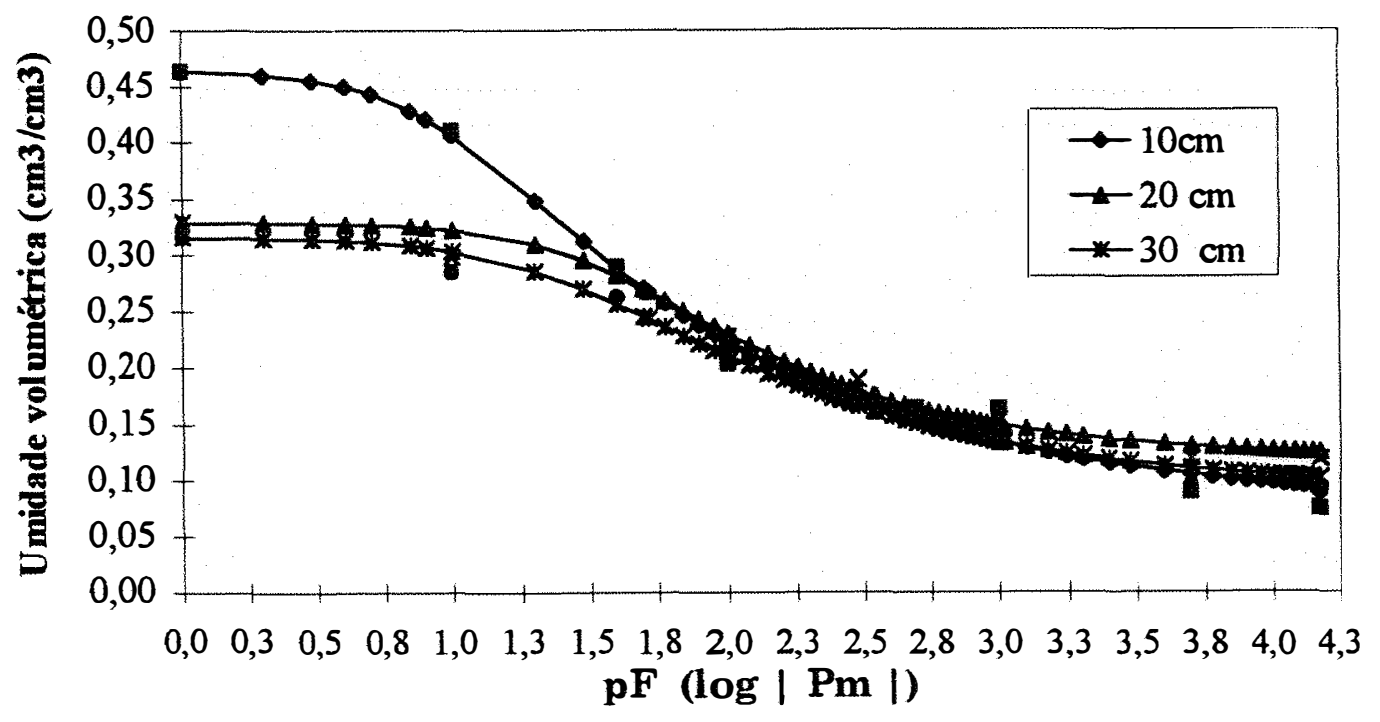

FIGURA 1 - Curva característica de retenção de água no solo, ajustada segundo GENUCHTEN (1980). 


\subsection{Plantio, cultivar e tratos culturais}

Para o plantio foi utilizado o cultivar Valenciano Amarelo CAC, tradicionalmente plantado pela maioria dos agricultores e que apresenta, segundo FERREIRA et al (1982), frutos lobular-alongados, pesando cerca de dois quilos, casca espessa, branco-creme, macia, apresentando um excesso de sementes. O sabor é agradável, doce em todos os frutos maduros, independentemente do tamanho deles. São muito resistentes ao manuseio e ao transporte a longas distâncias e apresentam boa durabilidade de pós-colheita.

No dia 13 de agosto de 1994 foram colocadas as sementes em bandejas de isopor para a formação de mudas em viveiro, utilizando o substrato de nome comercial Eucatex - Plantimax ${ }^{1}$. As sementes foram tratadas com Furadan SC. As mudas já em condições de transplante (com um par de folhas) foram levadas à campo no dia 4 de setembro do mesmo ano, portanto 20 dias após a semeadura.

O preparo do solo constituiu-se de uma aração e uma gradagem, com a incorporação de 8 tha de esterco de curral curtido, em área total, antes da primeira operação.

Um dia antes do transplante foram abertas as covas e aplicados em cada cova o adubo da fórmula 06 - 30 - 00, na forma fluida, sendo esta uma suspensão coloidal

1 A citação durante o texto de marcas e/ou produtos comerciais não configura recomendação do autor. 
$\left(\right.$ densidade $\left.=1,35 \mathrm{~g} \cdot \mathrm{cm}^{-3}\right)$. Considerando a densidade da solução, foram incorporados por hectare na adubação de plantio $40 \mathrm{~kg}$ de $\mathrm{N}$ e $200 \mathrm{~kg}$ de $\mathrm{P}_{2} \mathrm{O}_{5}$.

O transplante se deu no espaçamento de 2,0 metros entre linhas e 0,75 metros entre plantas, com uma planta por cova. A cultura foi conduzida de forma natural, ou seja, sem capação e sem desbrotas.

As adubações de coberturas foram realizadas em fertirngação, utilizando um injetor venturi. Foram realizadas em duas parcelas, aos 48 e 60 dias após a semeadura, nas doses de 5 e 5 gramas de $\mathrm{N}$ por planta e 5 e 5 g de $\mathrm{K}_{2} \mathrm{O}$ por planta, respectivamente. Foram utilizados os fertilizantes cloreto de potássio e Uram . O Uram é uma solução nitrogenada contendo $32 \%$ de $\mathrm{N}$ total, nas formas amídica, amoniacal e nítrica e a densidade do produto é $1,326 \mathrm{~g} \cdot \mathrm{cm}^{-3}$.

O controle fitossanitário foi realizado de acordo com as recomendações técnicas das áreas produtoras, com o cuidado de não se pulverizar o experimento no período da manhã, para não causar morte às abelhas polinizadoras. A relação dos defensivos utilizados se encontra na planilha de custo de produção.

\subsection{Simulador de veranico}

Para a realização do presente experimento foi necessário a incorporação à Área Experimental de Agricultura Irrigada um Simulador de Veranico (ver plantas anexo), que tornaria a área útil do experimento isenta da contribuição das chuvas. 
Foi elaborado então um projeto e até na implantação final foram necessárias várias adaptações. O Simulador de Veranico construído apresenta-se em estrutura metálica, coberta com folhas translúcidas transversais que possibilitam a passagem de $84 \%$ da luminosidade e $70 \%$ do calor, segundo catálogo do fabricante (FINEPLAST Ind. e Com. de Laminados Plásticos Ltda).

Com a estrutura, todo o desenvolvimento da cultura se deu através de água exclusivamente de irrigação, não havendo a menor interferência das chuvas.

O Simulador de Veranico possibilita o isolamento de uma área interna de 240 metros quadrados, pois a área interna possui um isolamento de $10 \times 24$ metros. Essa área é também isolada subterrâneamente em 1,80 metros, através de chapa galvanizada Com isso a água que cai nas laterais da estrutura não tem condições de infiltração para a área interna onde está plantada a cultura e onde estão os tratamentos.

O equipamento possui um vão livre mínimo de 2 metros de altura que possibilita a elaboração de pesquisas nas mais variadas culturas, pois a altura das plantas não é fator limitante. A parte frontal, bem como a de trás da estrutura é vedada das chuvas através de cortinas fabricadas em nylon trançado.

Diariamente, no início da noite a estrutura era deslocada até a área do experimento (área a ser isolada) para a proteção contra a eventual precipitação. No início do dia seguinte, toda a estrutura era novamente removida para a área de espera. Quando na iminência de chuvas durante o período diurno, a estrutura também era 
deslocada para a área a ser protegida (isolada). O Simulador de Veranico foi locado na direção Norte - Sul verdadeiro.

\subsection{Irrigação}

O experimento foi irrigado pelo método de irrigação por gotejamento, sendo instalado um gotejador por cova. O sistema de irrigação já existente é composto por um conjunto moto - bomba, cabeçal de controle composto de dois filtros de areia e um filtro de disco de 200 mesh. Ainda dispõe de injetor de fertilizante do tipo venturi. Os gotejadores do tipo "on line", foram avaliados em campo e em condições normais de operação, e apresentaram uma vazão média 2,3 litros por hora (C.V. $=9,71 \%$ e desvio padrão $=0,22$ ). A imigação foi realizada diariamente, iniciando-se no período da manhã e executada de modo a repor as perdas por evapotranspiração da cultura, esta estimada pelo método do Tanque Classe A e utilizando-se dos Coeficientes de Cultivo (Kc) propostos pela FAO (DOORENBOS e PRUITT, 1976 e DOORENBOS e KASSAM, 1988).

Durante a formação das mudas as irrigações foram realizadas 4 vezes ao dia, por período de 15 minutos, através de nebulizadores, visando o suprimento hídrico e principalmente a refrigeração do viveiro.

A expressão utilizada no cálculo da evapotranspiração cultural, base para o cálculo do tempo de irrigação, foi:

$$
E T c=E T o \quad K c \quad F C S
$$


onde: $\quad \mathrm{ETc}=$ evapotranspiração cultural, $\mathrm{mm} / \mathrm{dia}$;

$\mathrm{ETo}=$ evapotranspiração de referência, $\mathrm{mm} / \mathrm{dia}$;

$\mathrm{Kc}=$ coeficiente de cultura;

FCS $=$ fator de cobertura do solo.

O tempo de irrigação foi calculado pela expressão:

$$
T I=\frac{E \quad e \quad E T c}{n \quad q}
$$

onde: $\quad \mathrm{TI}=$ tempo de irrigação, horas;

$\mathrm{E}=$ espaçamento entre linhas, $\mathrm{m}$;

$\mathrm{e}=$ espaçamento entre plantas, $\mathrm{m}$;

$\mathrm{n}=$ número de gotejadores por planta;

$q$ = vazão do gotejadores, litros / hora;

Os coeficientes de cultura utilizados foram:

. Fase inicial - do transplante ao pegamento (tempo 0-t $\left.\mathrm{t}_{1}\right): 0,5$ (Fase I)

. Desenvolvimento vegetativo - do pegamento ao início do florecimento (tempo $t_{1}-t_{2}$ ):

1,1 (Fase II)

. Meio do ciclo - do florecimento ao início da formação dos frutos (tempo $t_{2}-t_{3}$ ): 1,1

(Fase III)

. Final do ciclo - do início da formação dos frutos ao início da colheita (tempo $\left.t_{3}-t_{4}\right)$ :

0,7 (Fase IV)

. Colheita - do início da colheita ao final do ciclo (tempo $\left.t_{4}-t_{5}\right): 0,7$ (Fase V) 
Os coeficientes de cultura foram utilizados segundo o esquema da Figura $2 \mathrm{e}$ os Kcs nos diferentes tempos foram calculados segundo as expressões a seguir:

$$
\begin{gathered}
\text { Para } 0 \leq \mathrm{t} \leq \mathrm{t}_{1} \rightarrow \mathrm{Kci}=0,5 \\
\text { Para } \mathrm{t}_{1} \leq \mathrm{t} \leq \mathrm{t}_{2} \Rightarrow K c i=\left(\frac{K c_{3}-K c_{1}}{t_{2}-t_{1}}\right)\left(t-t_{1}\right)+K c_{1} \\
\text { Para } \mathrm{t}_{2} \leq \mathrm{t} \leq \mathrm{t}_{3} \rightarrow \mathrm{Kci}=1,1 \\
\text { Para } \mathrm{t}_{3} \leq \mathrm{t} \leq \mathrm{t}_{4} \rightarrow K c i=\left(\frac{K c_{5}-K c_{3}}{t_{4}-t_{3}}\right)\left(t-t_{3}\right)+K c_{3} \\
\text { Para } \mathrm{t}_{4} \leq \mathrm{t} \leq \mathrm{t}_{5} \rightarrow \mathrm{Kci}=0,7
\end{gathered}
$$

onde:

$\mathrm{Kc}_{\mathrm{i}}$ é o coeficiente de cultura de interesse no i - ésimo dia após a emergência e $\mathbf{t}$ é o número de dias após a semeadura.

O FCS foi determinado à períodos de 3 dias medindo-se as dimensões dos ramos do meloeiro no sentido transversal às linhas de plantio e a seguir dividindo o valor obtido na leitura, pelo espaçamento de cultura (2,0 metros). Do transplante até o quadragésimo-quinto dia após a semeadura foi adotado um FCS de 30\%. 
Na Figura 3 pode se visualizado o comportamento da evapotranspiração cultural (ETc) e na Figura 4 os volumes de água aplicados por planta durante o experimento para o tratamento 7 (testemunha).

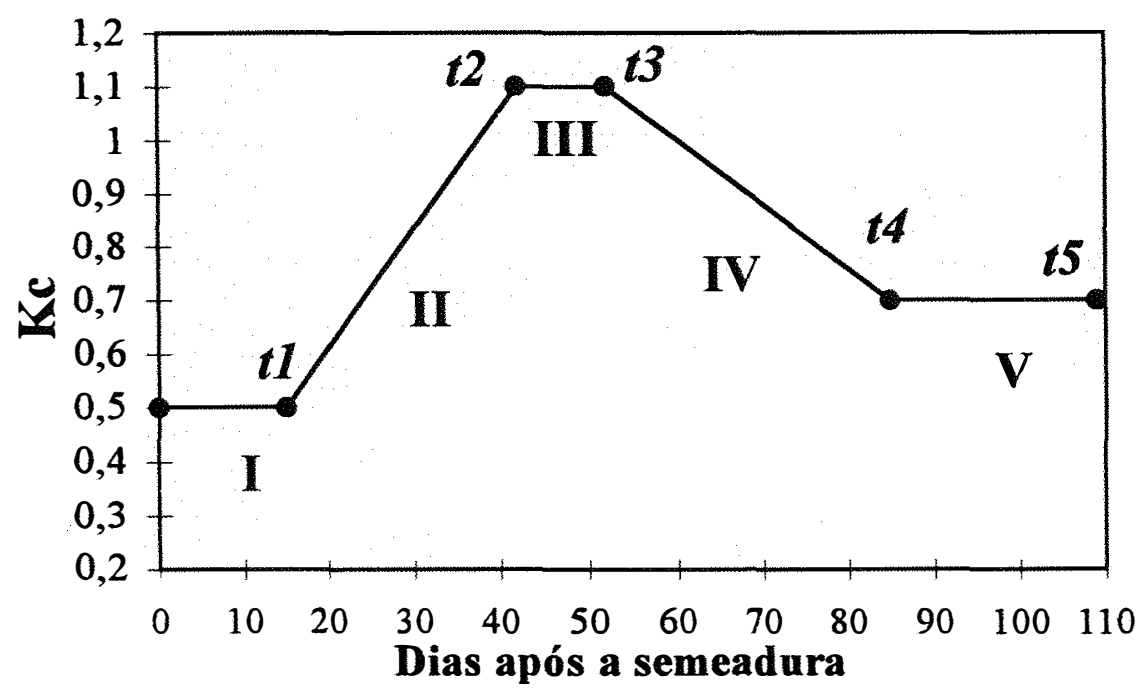

FIGURA 2 - Representação esquemática dos coeficientes de cultivo utilizado durante o experimento.

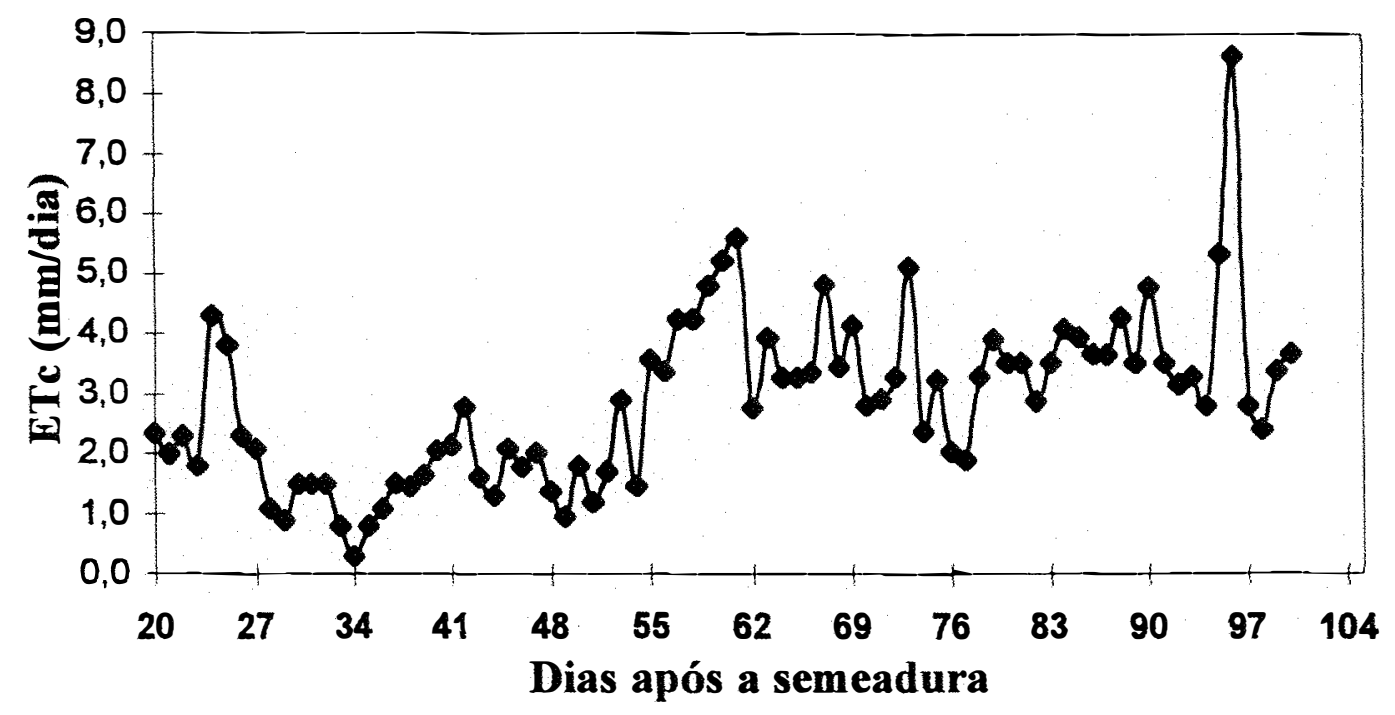

FIGURA 3 - Evapotranspiração cultural ( $\mathrm{mm} /$ dia) estimada pelo Tanque Classe A durante o experimento. 


\subsection{Tratamentos e análise estatística}

O presente experimento teve como tratamentos o estresse hídrico induzido à cultura do meloeiro em diferentes fases fenológicas da cultura e em duas intensidades. As intensidades foram caracterizadas pelos potenciais matriciais do solo (aproximadamente $-40 \mathrm{e}-80 \mathrm{kPa}$ ) à 15 centímetros de profundidade. Quanto atingidos estes potenciais, as plantas voltaram a ser imigadas normalmente.

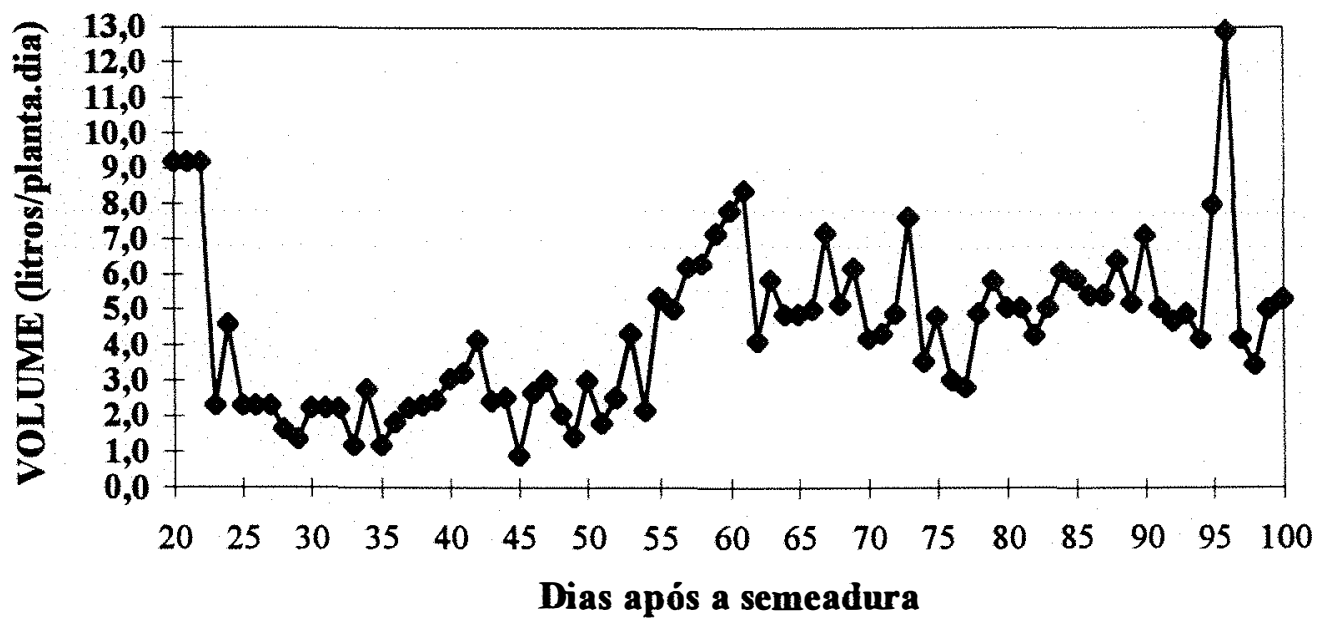

FIGURA 4 - Volume de água aplicado (litros/planta) durante o experimento no Tratamento 7 (testemunha).

Dessa maneira os tratamentos deste experimento foram:

$\mathrm{T}_{1}=$ estresse hídrico na fase vegetativa até $-40 \mathrm{kPa}$;

$\mathrm{T}_{2}=$ estresse hídrico na fase vegetativa até $-80 \mathrm{kPa}$; 
$\mathrm{T}_{3}=$ estresse hídrico do início do florescimento até $-40 \mathrm{kPa}$;

$\mathrm{T}_{4}=$ estresse hídrico do início do florescimento até - $80 \mathrm{kPa}$;

$\mathrm{T}_{5}=$ estresse hídrico na frutificação plena até $-40 \mathrm{kPa}$;

$\mathrm{T}_{6}=$ estresse hídrico na frutificação plena até $-80 \mathrm{kPa}$;

$\mathrm{T}_{7}=$ Testemunha (irrigação diária), sem restrição hídrica;

$\mathrm{T}_{8}=$ corte da água na fase de maturação até o final do ciclo.

O limite próximo a - $80 \mathrm{kPa}$ foi adotado tendo em vista que o monitoramento foi feito através de tensiômetros e este valor é próximo do limite de seu funcionamento.

O Quadro 5 traz os valores exatos do potencial matricial mínimo ocorrido em cada fase, o período de estresse e o número de dias decorridos com restrição hídrica.

QUADRO 5 - Potencial matricial mínimo, dias após a semeadura (D.A.S.), período e número de dias (N.D.) de restrição hídrica.

\begin{tabular}{cccccc}
\hline \multirow{2}{*}{ Tratamento } & Fase & $\Psi_{\mathbf{m}}(\mathbf{k P a})^{*}$ & D.A.S. & Período & N.D. \\
\hline 1 & Vegetativa (II) & $-33,9$ & $31 / 43$ & 13 a 25/09/94 & 12 \\
\hline 2 & Vegetativa (II) & $-76,1$ & $31 / 48$ & 13 a 30/09/94 & 17 \\
\hline 3 & Florescimento (III) & $-42,4$ & $51 / 58$ & 02 a 09/10/94 & 7 \\
\hline 4 & Florescimento (III) & $-78,4$ & $51 / 60$ & 02 a 11/10/94 & 9 \\
\hline 5 & Frutificação (IV) & $-58,8$ & $64 / 69$ & 15 a 20/10/94 & 5 \\
\hline 6 & Frutificação (IV) & $-76,63$ & $64 / 70$ & 15 a 21/10/94 & 6 \\
\hline 7 & Testemunha & $-43,1$ & - & - & - \\
\hline 8 & Fnutificação (IV) & $-82,3$ & $75 / 109$ & $25 / 10 / 94$ ao final & 34 \\
& Colheita (V) & & & & \\
\hline
\end{tabular}

* Tensiômetro instalado à 15 centímetros de profundidade. 
Os tratamentos foram dispostos em pequenas parcelas (4 plantas por parcela, totalizando uma área útil de $6 \mathrm{~m}^{2}$ ), no interior do Simulador de Veranico e cada tratamento recebeu sua linha de gotejadores munidos de registros de esfera (acionamento rápido), que possibilitava o corte da água no momento certo, sem comprometer os outros tratamentos.

A área ao redor do Simulador foi também plantada com melão, de modo a oferecer uma grande área de bordadura, de modo a diminuir ou até eliminar o efeito oásis.

A análise estatística dos dados foi efetuada segundo o delineamento inteiramente casualizado (DIC), com 8 tratamentos e 4 repetições e para tal os dados foram processados pelo software SANEST (ZONTA e MACHADO, 1991).

\subsection{Parâmetros avaliados}

\subsubsection{Desenvolvimento da cultura}

O desenvolvimento da cultura foi dividido em estádios fenológicos de acordo com observações de caráter morfológico. Esses estádios foram assim distribuídos:

- Emergência de plantas e estádio inicial: estende-se da semeadura até a emergência de $50 \%$ mais uma planta e posteriormente até o transplante (FASE I);

- Vegetativo: estende-se do final do ciclo anterior até que 50\% mais uma planta apresentem flores femininas (FASE II); 
- Florescimento ou reprodutivo: estende-se do final do ciclo anterior até que 50\% mais uma planta apresentem frutos (FASE III);

- Frutificação: do final do ciclo anterior até o início da colheita (FASE IV);

- Colheita: do final do ciclo anterior até a última colheita (FASE V).

Nas condições do presente experimento, a fase I foi desenvolvida em viveiro, durante a formação das mudas.

\subsubsection{Produção de frutos}

Através de pesagens individuais dos frutos provenientes das parcelas foi estimada a produtividade $(\mathrm{kg} / \mathrm{ha})$ ocorrida nos tratamentos. As colheitas foram realizadas nos dias 05, 13, 22 e 29 de novembro de 1994.

\subsubsection{Dimensões dos frutos}

Em cada colheita foi efetuada a contagem do número de frutos e suas dimensões (altura e diâmetro), estas feitas através de uma calha graduada Desse modo são apresentados os valores correspondentes às médias das parcelas, sendo seus valores determinados pela soma dos valores obtidos em cada colheita dividido pelo número de frutos.

\subsubsection{Peso médio de frutos}

O valor apresentado corresponde ao valor médio de cada parcela ao longo da safra, este calculado pela somatória dos valores obtidos em cada colheita, dividido pelo número total de frutos.

\subsubsection{Teor de sólidos solúveis, acidez titulável e Índice de Maturação.}


Após cada colheita de cada tratamento foram realizadas as análises laboratoriais com a finalidade de se obter os teores correspondentes de sólidos solúveis, acidez titulável e o cálculo do Índice de Maturação (relação entre sólidos solúveis e a acidez titulável).

Os teores de sólidos solúveis (Brix) foram obtidos através de leitura em refratômetro com os frutos completamente mađuros.

A acidez titulável foi detenninada utilizando-se uma alíquota de $10 \mathrm{ml}$ do suco de polpa, a qual se adicionaram 3 gotas de fenolftaleína 1\%. A seguir foi feita a titulação até o ponto de viragem com solução $\mathrm{NaOH}(0,1 \mathrm{~N})$, previamente padronizada, segundo metodologia proposta pelo INSTITUTO ADOLFO LUTZ (1985). As análises foram realizadas no dia seguinte à colheita e os resultados estão expressos em porcentagem de ácido málico.

\subsubsection{Eficiência do uso da água (e.u.a.)}

De acordo com DOORENBOS e KASSAM (1988), a eficiência do uso da água (e.u.a.) pode ser determinada tanto para a produtividade biológica, como para a produtividade de frutos. Neste caso foi determinada para a produção final de frutos.

A determinação da eficiência do uso da água para a produção final foi feita através da relação entre o peso total de frutos $(\mathrm{kg} / \mathrm{ha})$ e o consumo de água $\left(\mathrm{m}^{3} / \mathrm{ha}\right)$ durante o ciclo da cultura. 


\subsubsection{Potencial matricial da água do solo}

O potencial matricial ou potencial matricial de água no solo foi determinado diariamente através de tensiômetros com manômetro de mercúrio (REICHARDT, 1985), instalados nas profundidades de 15,30 e 45 centímetros. As leituras provenientes destes aparelhos foram posteriormente convertidas em umidade do solo e \% da CAD através do modelo proposto por GENUCHTEN (1980). As leituras foram sempre feitas a partir das 08:00 horas e anterior às irrigacõos, portanto as leituras refletem as condições mais adversas sofridas pelas plantas em relação ao suprimento hídrico.

A CAD (Capacidade de Água Disponível) foi calculada segundo a expressão:

$$
\mathrm{CAD}=\left(\theta_{\mathrm{CC}}-\theta_{\mathrm{PMP}}\right) \times \mathrm{PESR}
$$

onde: $\theta_{\mathrm{CC}}=$ umidade volumétrica $\left(\mathrm{cm}^{3} . \mathrm{cm}^{-3}\right)$ na capacidade de campo;

$\theta_{\mathrm{PMP}}=$ umidade volumétrica $\left(\mathrm{cm}^{3} \cdot \mathrm{cm}^{-3}\right)$ no ponto de murchamento permanente;

PESR $=$ profundidade efetiva do sistema radicular $(\mathrm{mm})$.

A CAD atual foi calculada pela expressão:

$$
\mathrm{CAD} \text { atual }=\left(\theta \mathrm{a}-\theta_{\mathrm{PMP}}\right) \times \mathrm{PESR}
$$

onde: $\quad \theta a=$ umidade atual, $\mathrm{cm}^{3} / \mathrm{cm}^{3}$. 
A \% da CAD foi calculada pela expressão:

$$
\% \mathrm{CAD}=\left(\mathrm{CAD}_{\text {atual }} / \mathrm{CAD}\right) \times 100
$$

\subsubsection{Crescimento de raízes}

Ao final do ciclo da cultura foram realizadas amostragens de raízes das plantas com o objetivo de se verificar a influência dos tratamentos sobre o crescimento de raízes. A determinação foi feita em camadas de 10 centímetros, da superficie até 30 centímetros de profundidade e em uma extensão de 30 centímetros na superficie, com o caule da planta ao centro, ou seja foram retiradas as raízes nas distâncias de 15 centímetros que circundavam as plantas. Foi utilizado o método gravimétrico e o resultado expresso em porcentagem do total de raízes amostradas.

As amostras foram retiradas através de um trado de caneca com $88,9 \mathrm{~mm}$ de diâmetro. Posteriormente o solo com as raízes foram secos à sombra e separadas as raízes da terra através de catação manual e peneira com abertura de 0,42 mm (ABNT 40 , Tyler $=35)$. As raízes foram secas em estufa $\left(105^{\circ} \mathrm{C}\right)$ de circulação forçada de ar até peso constante e a seguir pesadas em balança eletrônica.

\subsection{Custo de produção}

Todas as operações e produtos utilizados na cultura durante o experimento foram anotadas de modo a estimar o custo de produção da cultura nas condições de Illha Solteira. 
Foi projetado um sistema completo de irrigação por gotejamento para uma área de 1,0 hectare para a irrigação da cultura do melão e o custo foi elaborado por uma empresa de projetos e comercialização de sistemas de inigação da região. Para a elaboração da planilha de custo de produção, foi considerada uma vida útil do equipamento de 6 anos e um plantio por ano. O custo total de implantação da irrigação por gotejamento na cultura foi orçado em $\mathrm{R} \$ 4.564,00$ ou US\$4.804,21.

Os preços dos insumos foram coletados junto aos distribuidores locais e o preço de venda dos melões foram calculados segundo o divulgado por CEAGESP (1994), com um redutor de $20 \%$. Foi considerado o valor médio de comercialização do mês de novembro e o preço das caixas de 13 kilos, tipo 8 . 


\section{RESULTADOS E DISCUSSÃO}

\subsection{Desenvolvimento da cultura}

O ciclo da cultura e o crescimento das plantas durante o expenimento podem ser observados no Quadro 6 e Figura 5. Verifica-se que o ciclo da cultura variou entre 101 e 108 dias, devido ao fato de que nos tratamentos 3 e 7 foram realizadas apenas três colheitas, contra quatro nos demais tratamentos.

QUADRO 6 - Números de dias de cada estádio fenológico e ciclo total da cultura nos diferentes tratamentos.

\begin{tabular}{|c|c|c|c|c|c|c|c|c|}
\hline TRATAMENTOS & $\mathrm{T}_{1}$ & $\mathbf{T}_{2}$ & $T_{3}$ & $\mathbf{T}_{4}$ & $T_{5}$ & $T_{6}$ & $\mathbf{T}_{7}$ & $\mathbf{T}_{8}$ \\
\hline Germinação & 4 & 4 & 4 & 4 & 4 & 4 & 4 & 4 \\
\hline $\begin{array}{l}\text { Formação da muda e } \\
\text { transplante (Fase I) }\end{array}$ & 16 & 16 & 16 & 16 & 16 & 16 & 16 & 16 \\
\hline $\begin{array}{c}\text { Desenvolvimento vegetativo } \\
\text { (Fase I) }\end{array}$ & 20 & 20 & 20 & 20 & 20 & 19 & 19 & 19 \\
\hline Florescimento (Fase III) & 11 & 10 & 10 & 12 & 10 & 9 & 9 & 10 \\
\hline Frutificação(fase IV) & 33 & 34 & 34 & 31 & 34 & 35 & 35 & 34 \\
\hline Colheita (Fase V) & 24 & 24 & 17 & 24 & 24 & 24 & 17 & 24 \\
\hline TOTAL & 108 & 108 & 101 & 108 & 108 & 108 & 101 & 108 \\
\hline
\end{tabular}

TYLER e LORENTZ (1964), BELFORT et al (1986), SOUZA (1993), em regiões edafo-climáticas distintas tiveram um ciclo da cultura de 107, 75 e 109 dias, 
respectivamente. Uma análise mais detalhada do trabalho de SOUZA (1993) realizado em São Manoel, Estado de São Paulo, onde foi utilizado, à semelhança deste trabalho, o sistema de formação de mudas e posterior transplantio para o campo, mostra que a Fase I, que vai da semeadura ao transplantio em campo foi de 26 dias, contra 20 dias para as condições de Tha Solteira.

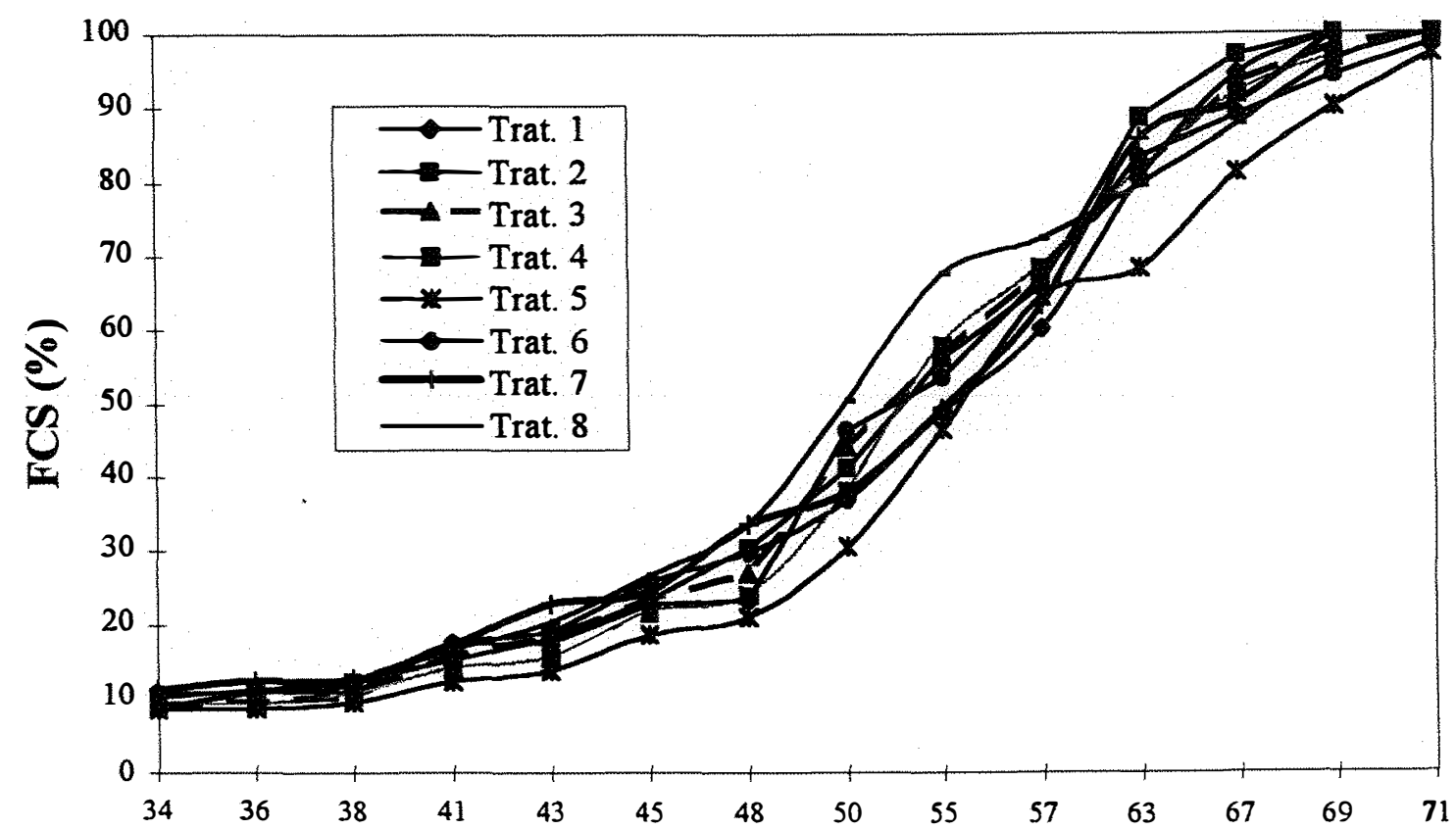

Dias após a semeadura

FIGURA 5 - Fator de cobertura do solo observado para os diferentes tratamentos.

No entanto, os resultados de BELFORT et al (1986) mostram diferenças consideráveis no ciclo da cultura, levando a crer que as condições climáticas locais podem oferecer grandes diferenças no crescimento e desenvolvimento das plantas. 
Em Itha Solteira, BUZETTI et al (1993) obtiveram ciclos de 85 e 93 dias para a produção final dos cultivares Valenciano Amarelo e Eldorado 300, respectivamente. A semeadura do cultivar Valenciano Amarelo foi feita em agosto e a Fase I e II somaram 33 dias contra 40 dias obtidos neste experimento. As Fases III, IV e V do experimento de BUZETTI et al (1993) duraram respectivamente 9, 22 e 21 dias contra 11, 33 e 24 dias obtidos no presente trabalho. BEDUM et al (1993) em experimento de lâminas de irrigação, também em Ilha Solteira e plantio de agosto, relatam um ciclo de 80 dias após a semeadura, porém ressaltam que por problemas fitossanitários, a colheita foi única, o que levou a um encurtamento do ciclo da cultura.

DUSI (1992) relata que na região Nordeste do País, as frutas começam a ser colhidas aos 55-60 dias após a semeadura, com o ciclo se prolongando por cerca de 100 dias, com até cinco colheitas.

Do ponto de vista prático e econômico, a utilização do sistema de mudas e transplantio leva à um pequeno atraso no ciclo final da cultura, mas é de longe compensado por 20 dias (período em que as mudas estão no viveiro) em que não se faz capinas, não se irriga e principalmente, não se faz pulverizã̧̧es, uma vez que tratamento fitossanitário assume uma grande parcela do custo de produção da cultura. As imigações dentro do viveiro são feitas a um custo muito baixo e normalmente se utiliza a própria caixa d'água como fonte de energia para impulsionar os nebulizadores. 
A análise da Figura 5 mostra que o crescimento dos ramos do meloeiro, expresso através do Fator de Cobertura do Solo (FCS) apresentou pequenas variações em número, porém apresenta grande semelhança de forma. Não obstante os Tratamentos 3 e 4 alcançaram um recobrimento de $100 \%$ aos 69 dias, enquanto que os demais tratamentos somente alcançaram tal índice aos 71 dias após a semeadura

A observação do crescimento assume importância quando se pensa na utilização da fertirngação, com injeção parcelada dos nutrientes. Nestes casos, os programas de fertinigação devem levar em conta o crescimento da cultura com a conseqüente absorção maior dos nutrientes por parte das plantas. SOUZA (1993) mostra que aplicações mais freqüentes de fertilizantes nitrogenados e potássicos não influenciam no aumento da taxa de crescimento das plantas de melão e conseqüente aumento no acúmulo de matéria seca total, porém tem revelado maior eficiência no acúmulo de matéria seca e maior eficiência na conversão desta em partes da planta de maior expressão econômica, com maior produção de frutos por unidade de área. A maior produção de frutos por uma mesma unidade de área certamente traz maiores receitas ao produtor.

Para as condições deste experimento, as maiores taxas de crescimento das plantas foram observadas entre 48 e 67 dias após a semeadura, sendo este provavelmente também o período de maior absorção de nutrientes pela cultura, onde deve-se dar condição à cultura de um bom suprimento nutricional. TYLER e LORENZ (1964) relatam que o período de maior crescimento das plantas está entre 
70 e 80 dias, enquanto BELFORT et al (1986) encontraram o período entre 30 e 45 dias após a emergência como o de maior crescimento das plantas.

\subsection{Aspectos produtivos}

No Quadro 7 são apresentados os parâmetros produtivos da cultura do melão e a relação entre as produtividades obtidas nos diferentes tratamentos está ilustrada na Figura 6. A análise estatística mostra que somente a produtividade de frutos comerciais foi afetada pelos tratamentos, não havendo diferenças estatísticas entre os tratamentos nos demais parâmetros produtivos.

Em um dos poucos trabalhos que analisam a supressão hídrica na cultura do meloeiro, RITSCHEL et al (1994) estudaram o momento de cessar a irrigação e não encontraram diferenças estatísticas na produtividade comercial, peso médio de fruto e total de frutos por planta, quando a última irrigação foi feita aos 56,63 ou 70 dias após a semeadura. Ressalta-se que o trabalho foi desenvolvido no nordeste brasileiro, em condições semi-áridas.

Os dados obtidos levam à confirmação de que a origem do meloeiro talvez possa ser mesmo de regiões de deserto, pois suporta baixa umidade do solo e no caso de excesso de água podem ter sua produtividade prejudicada As melhores produtividades obtidas nos tratamentos 1 e 2 levam à confirmação deste fato. Todos os tratamentos receberam água igualmente, enquanto no início da cultura, com pouca massa de raízes, a cultura suportou a falta de água ou, com a supressão hídrica, o teor 
de água no solo tornou-se adequado, enquanto que os demais tratamentos ao receberem água regularmente podem ter sofrido pelo provável excesso de água e com pequena massa de raizes, estas teriam sentido a falta da aeração no solo. $\mathrm{Na}$ fase inicial da cultura, o potencial matricial, na pior condição para as plantas (leitura dos tensiômetros antes da inigação), sempre ficou em valores entre 0 e $-10 \mathrm{kPa}$, fato este que leva ao solo valores de umidade muito superior à $\mathrm{CAD}$, portanto com água ocupando quase todos os macro e microporos, colocando a porosidade livre de água à níveis não aceitáveis.

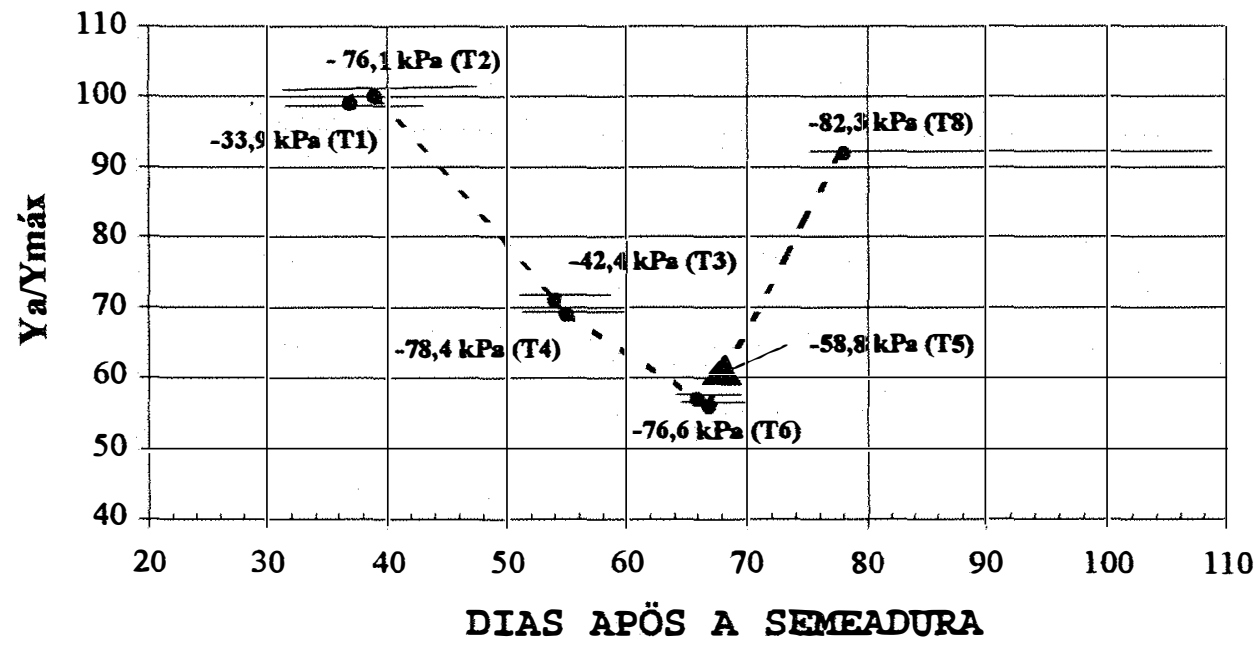

FIGURA 6 - Relações entre produtividade atual e produtividade máxima $\left(\mathrm{Y}_{\mathrm{a}} / \mathrm{Y}_{\max }\right)$ obtidas em função dos tratamentos empregados.

FILGUEIRA (1981) afirma que a falta de água na fase inicial da cultura leva à uma desuniformidade na emissão de flores e formação de frutos ao longo do ciclo 
da cultura, fato observado entre os tratamentos, porém não refletindo na produtividade final, uma vez que os tratamentos 3,4 e 7 (testemunha) apresentaram resultados semelhantes.

As maiores produtividades obtidas nos Tratamentos 1 e 2 se devem ao fato de que estes acabaram por produzir em 39,7 e $37,2 \%$ mais frutos por planta de que a testemunha, mesmo a custa da produção de frutos de menor peso, porém, quando somados acabam por resultar em ganhos de produtividade.

A análise detalhada da Figura 6 mostra que existe um comportamento definido da cultura em relação ao déficit hídrico e a fase fenológica em que este ocorreu. As diferenças na relação produtividade atual $\left(\mathrm{Y}_{\mathrm{a}}\right)$ e produtividade máxima ( $Y_{\text {máx }}$ em uma mesma fase fenológica são pequenas, enquanto que se a comparação se der entre potenciais matriciais e fases fenológicas, estas são acentuadas. Os resultados corroboram parcialmente com a afimação de DOORENBOS e PRUITT (1976) que colocam como críticas para a cultura as fases que vão do florescimento à colheita. À rigor, a fase que mais sofreu com o défici hídrico foi a da frutificação, seguida da fase de florescimento.

Numericamente, as menores produtividades foram obtidas quando a irrigação foi cessada durante o período da frutificação, a partir de 64 dias após a semeadura. Durante este período a extração de água pelas plantas é muito intensa e este fato pode ser confirmado pelo número de dias de supressão hídrica necessários para atingir o potencial matricial crítico. Enquanto que na fase vegetativa foram necessários 17 dias 


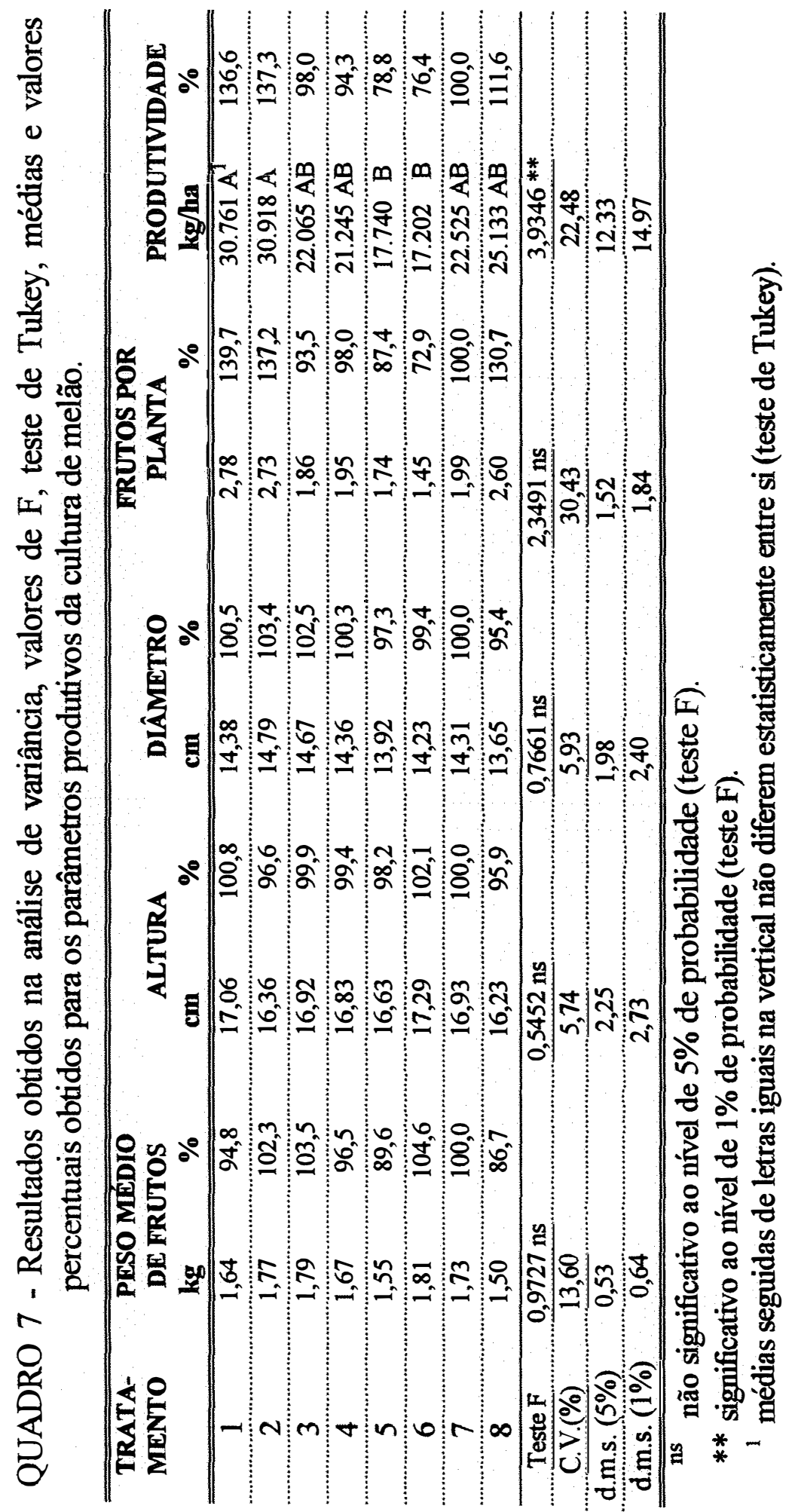


de supressão hídrica para se atingir um potencial matricial de $-76,1 \mathrm{kPa}$, no Tratamento 6 (fase de frutificação) com apenas 6 dias se atingiu o crítico, voltando portanto a ser praticada a irrigação.

Durante a frutificação, e após os primeiros frutos iniciarem sua mudança de coloração (75 dias após a semeadura), o cessamento da imigação não levou a grandes quedas de produtividades. Isto ocorreu porque provavelmente, as reservas de água no solo e da planta foram suficientes para manterem os processos fisiológicos e bioquímicos em atividades.

BUZETTI et al (1993) encontraram produtividades máximas de melão da ordem de 23 tha, RITSCHEL et al (1994), 42 tha (primeiro ano) e 24,5 tha (segundo ano) e BEDUM et al (1993), 21 tha. As produtividades obtidas no presente experimento levam à confirmação da aptidão climática da região para o cultivo do melão, assumindo assim, papel de agente diversificador da agricultura regional.

Os resultados obtidos não comoboram com FERREIRA (1982), que relata a necessidade de diminuição da frequência de imigação. Nas condições deste experimento, a fase fenológica da cultura mais afetada pela ausência da irrigação foi justamente a frutificação.

Estatisticamente, os resultados apresentados concordam com DAN (1974), que não encontraram influência marcante da quantidade de água fornecida na produção. 
O peso médio dos frutos durante a safra toda acabou por caracterizar uma produção de frutos do tipo 8 (caixa de 13 quilos $\pm 0,65 \mathrm{~kg}$ ) para todos os tratamentos, à exceção dos Tratamentos 5 e 8, que resultaram em uma produção média de frutos tipo 10, devido ao peso unitário de seus frutos (Quadro 7).

Uma análise mais precisa do tipo de fruto colhido e a quantificação da safra deve ser feita através dos dados do Quadro 8, que traz os parâmetros produtivos da cultura em cada colheita.

Através deste quadro verifica-se que nos Tratamentos 2,3 e 7 , é a segunda colheita a de maior expressão, enquanto que os Tratamentos 1, 4, 5 e 6 tiveram a terceira colheita como a mais expressiva. $O$ Tratamentos 7 e 8 , que não sofreram déficits hídricos durante as fases iniciais e medianas da cultura, tiveram uma melhor distribuição da produção durante as colheitas. Convém frisar que quarta colheita do Tratamento 8 pode ser considerada muito baixa perante as colheitas anteriores. Portanto, pode-se concluir que um bom suprimento hídrico na cultura até os 75 dias após a semeadura (no caso, frutos iniciando o processo de amarelecimento) leva uma melhor distribuição da colheita, corroborando com RITSCHEL et al (1994), que numericamente encontraram melhores produtividades quando a imigação foi cessada aos 70 dias após a semeadura, em dois anos de plantio.

OLITTA et al (1978) em experimento de comparação de métodos de imigação, observaram que as segunda e terceira colheitas foram as mais 
produtivas, enquanto que PHENE et al (1987) tiveram nas primeira e segunda colheitas, as mais produtivas.

QUADRO 8 - Parâmetros produtivos obtidos para frutos de melão em cada colheita.

\begin{tabular}{|c|c|c|c|c|c|}
\hline $\begin{array}{l}\text { Trata- } \\
\text { mento }\end{array}$ & $\begin{array}{l}\text { Colheitas } \\
\text { data }\end{array}$ & $\begin{array}{c}\text { Peso } \\
\text { médio (kg) }\end{array}$ & $\begin{array}{l}\text { Comprimento } \\
\text { médio }(\mathbf{c m})\end{array}$ & $\begin{array}{l}\text { Diâmetro } \\
\text { médio }(\mathrm{cm})\end{array}$ & $\begin{array}{l}\text { Produtividade } \\
\text { média (t/ha) }\end{array}$ \\
\hline 1 & $05 / 11 / 94$ & 1,76 & 17,25 & 15,00 & 4,34 \\
\hline 1 & $13 / 11 / 94$ & 1,67 & 15,35 & 14,33 & 10,75 \\
\hline 1 & $22 / 11 / 94$ & 1,69 & 18,24 & 14,22 & 13,70 \\
\hline 1 & $29 / 11 / 94$ & 1,24 & 16,00 & 13,00 & 1,97 \\
\hline 2 & $05 / 11 / 94$ & $\overline{1,68}$ & 15,39 & 15,28 & $\overline{4,92}$ \\
\hline 2 & $13 / 11 / 94$ & 1,99 & 15,44 & 15,19 & 14,85 \\
\hline 2 & $22 / 11 / 94$ & 1,77 & 17,61 & 14,89 & 7,62 \\
\hline 2 & 29/11/94 & 1,11 & 17,10 & 12,20 & 3,53 \\
\hline 3 & $05 / 11 / 94$ & 2,07 & 18,38 & 15,50 & 4,27 \\
\hline 3 & $13 / 11 / 94$ & 1,70 & 16,05 & 15,00 & 13,28 \\
\hline 3 & $22 / 11 / 94$ & 1,57 & 16,35 & 13,50 & $-4,52$ \\
\hline 4 & $05 / 1 \overline{1} / 94$ & $1, \overline{8} 0$ & 15,00 & $\overline{16}, \overline{0} \overline{0}$ & $\overline{0,75}$ \\
\hline 4 & $13 / 11 / 94$ & 1,65 & 15,92 & 14,15 & 8,14 \\
\hline 4 & $22 / 11 / 94$ & 1,85 & 17,63 & 15,17 & 9,93 \\
\hline 4 & $29 / 11 / 94$ & 1,28 & 17,00 & 13,00 & 2,43 \\
\hline 5 & $05 / 11 / 94$ & $\overline{1}, \overline{84}$ & 15,00 & 15,00 & $\overline{0}, \overline{7} \overline{7}$ \\
\hline 5 & $13 / 11 / 94$ & 1,59 & 15,42 & 13,33 & 5,38 \\
\hline 5 & $22 / 11 / 94$ & 1,54 & 17,54 & 14,33 & 11,23 \\
\hline 5 & 29/11/94 & 0,90 & 18,00 & 12,00 & 0,37 \\
\hline-6 & $05 / 1 \overline{1} / 94$ & 1,57 & 15,50 & 14,00 & $1, \overline{85}$ \\
\hline 6 & $13 / 11 / 94$ & 2,15 & 18,00 & 13,83 & 5,33 \\
\hline 6 & $22 / 11 / 94$ & 1,77 & 16,78 & 14,72 & 7,94 \\
\hline 6 & $29 / 11 / 94$ & 1,67 & 19,00 & 14,50 & 2,09 \\
\hline 7 & $05 / 11 / 94$ & 2,28 & 18,71 & 16,79 & 6,33 \\
\hline 7 & $13 / 11 / 94$ & 1,65 & 15,38 & 13,71 & 9,38 \\
\hline 7 & $22 / 11 / 94$ & 1,26 & 16,71 & 12,42 & 6,82 \\
\hline 8 & $05 / 11 / 94$ & 1,61 & 16,54 & 14,73 & $\overline{9,07}$ \\
\hline 8 & $13 / 11 / 94$ & 1,47 & 14,89 & 12,73 & 9,02 \\
\hline 8 & $22 / 11 / 94$ & 1,60 & 16,48 & 14,27 & 6,18 \\
\hline 8 & 29/11/94 & 1,04 & 17,50 & 12,00 & 0,87 \\
\hline
\end{tabular}

A análise dos diferentes experimentos leva a conclusão de que possívelmente definição da forma de composição da colheita final esteja associada ao desenvolvimento da planta e ao estado fitossanitário da cultura. Via de regra, 
problemas com doenças, especialmente mil dio e oídio, podem encurtar o ciclo da cultura. O desenvolvimento da cultura (formação de biomassa) está certamente correlacionada com o fornecimento de água e nutrientes.

\subsection{Aspectos qualitativos}

Os aspectos qualitativos dos frutos de melão: teor de sólidos solúveis ( ${ }^{\circ}$ Brix), acidez titulável e índice de maturação obtidos podem ser observados no Quadro 9. YAMAGUCH et al (1977) relatam que na quantificação dos aspectos qualitativos é o Brix o principal fator que determina a melhor ou pior qualidade dos frutos. Estes autores trabalharam com os aspectos qualitativos dos frutos de melão e obtiveram uma ampla variação de resultados. Consideram $9^{\circ}$ Brix como o mínimo aceitável para o consumo. AULENBAUCH e WORTHINGTON (1974) questionam o teor de sólidos solúveis como único critério para se definir a qualidade do fruto. Assim mesmo, sugerem a faixa considerada ideal, que se situa entre 8 e $13^{\circ}$ Brix.

A primeira colheita trouxe tanto para o Brix, como para a acidez titulável e índice de maturação diferenças entre os tratamentos, sendo que estas podem ser atribuídas as diferenças na entrada de produção dos frutos, conforme pode ser observado no Quadro 8.

Os valores de Brix obtidos foram superiores aos encontrados por BUZETTI et al (1993), SOUZA (1993), RITSCHEL et al (1994), ainda que, segundo DAVIS e SCHWEERS (1971), o teor de sólidos solúveis varia tanto com 
o local, quanto de fruto para fruto em algumas plantas. Ainda assim, as variações entre tratamentos não seguem uma tendência, em função da maior ou menor quantidade de água no solo e em cada fase da cultura.

QUADRO 9 - Resultados obtidos na análise de variância, teste F, teste de Tukey e médias obtidas para os parâmetros qualitativos dos frutos de melão colhidos em novembro de 1994, em Iha Solteira, SP.

\begin{tabular}{|c|c|c|c|c|c|c|c|}
\hline \multirow{2}{*}{$\begin{array}{c}\text { TRATA- } \\
\text { MEN- } \\
\text { TO }\end{array}$} & \multicolumn{3}{|c|}{ BRIX } & \multicolumn{2}{|c|}{$\begin{array}{c}\text { ACIDEZ } \\
\text { TITULÁVEL }\end{array}$} & \multicolumn{2}{|c|}{$\begin{array}{l}\text { TNDICE DE } \\
\text { MATURAÇÃO }\end{array}$} \\
\hline & DIA 6 & DIA 14 & DIA 22 & DIA 6 & DIA 14 & DIA 6 & DIA 14 \\
\hline 1 & $11,29 \mathrm{AB}^{1}$ & 11,42 & 10,46 & $14,27 \mathrm{AB}$ & 15,07 & $0,79 \mathrm{AB}$ & $0,77 \mathrm{AB}$ \\
\hline 2 & $10,95 \quad$ B & 11,82 & 9,66 & $16,53 \mathrm{~A}$ & 14,24 & $0,67 \quad$ B & $0,87 \mathrm{~A}$ \\
\hline 3 & $11,17 \mathrm{AB}$ & 11,14 & 10,91 & $15,24 \mathrm{AB}$ & 15,41 & $0,73 \quad B$ & $0,72 \mathrm{AB}$ \\
\hline 4 & $12,14 \mathrm{AB}$ & 11,77 & 9,79 & $16,75 \mathrm{~A}$ & 16,41 & $0,73 \quad B$ & $0,72 \mathrm{AB}$ \\
\hline 5 & $11,24 \mathrm{AB}$ & 10,64 & 9,81 & $12,73 \quad B$ & 18,09 & $0,90 \mathrm{~A}$ & $0,59 \quad \mathrm{~B}$ \\
\hline 6 & $12,39 \mathrm{~A}$ & 10,37 & 9,84 & $16,95 \mathrm{~A}$ & 15,41 & $0,73 \quad$ B & $0,67 \mathrm{AB}$ \\
\hline 7 & $11,54 \mathrm{AB}$ & 11,49 & 11,09 & $15,58 \mathrm{~A}$ & 14,91 & $0,74 \quad$ B & $0,77 \mathrm{AB}$ \\
\hline 8 & $11,24 \mathrm{AB}$ & 12,17 & 9,93 & $15,91 \mathrm{~A}$ & 18,59 & $0,71 \quad B$ & $0,67 \quad \mathrm{~B}$ \\
\hline Teste F & $3,749^{* *}$ & $2,159 \mathrm{~ns}$ & $2,703 \mathrm{~ns}$ & $6,157 * *$ & 2,309 & 4,628 ** & $2,297 \mathrm{~ns}$ \\
\hline C.V.(\%) & 4,6 & 7,3 & 6,7 & 7,4 & 12,8 & 8,6 & 15,1 \\
\hline d.m.s. (5\%) & 1,23 & 1,94 & 1,59 & 2,68 & 4,82 & 0,15 & 0,26 \\
\hline d.m.s. $(1 \%)$ & 1,49 & 2,35 & 1,93 & 3,26 & 5,84 & 0,18 & 0,31 \\
\hline
\end{tabular}

ns não significativo ao nível de $5 \%$ de probabilidade (teste $\mathrm{F}$ ).

** significativo ao nível de $1 \%$ de probabilidade (teste F).

${ }^{1}$ médias seguidas de letras diferentes na vertical diferem estatisticamente entre si.

DUSI (1992) relata que o sabor e a textura dos frutos melhoram após a colheita por alguns dias e os frutos colhidos com o máximo teor de açúcar atingem, assim, sua melhor qualidade. No entanto, um fruto com um alto teor de açúcar pode ter seu sabor prejudicado em função de um também alto valor de ácido titulável, dai a avaliação da acidez titulável. Ainda segundo este autor, para a região Nordeste do Brasil, os frutos são colhidos com $9^{\circ}$ Brix, valor bastante 
inferior ao alcançado no experimento, evidenciando também a potencialidade qualitativa dos frutos da região para a produção da cultura.

\subsection{Potencial matricial da água do solo e umidade}

Nas Figuras 7 a 14 são apresentadas as variações do potencial matricial de água no solo (em módulo) ocorridas durante o experimento e em seguida a \% da CAD equivalente. Com o segundo gráfico (b) é possível verificar o esgotamento da água do solo.
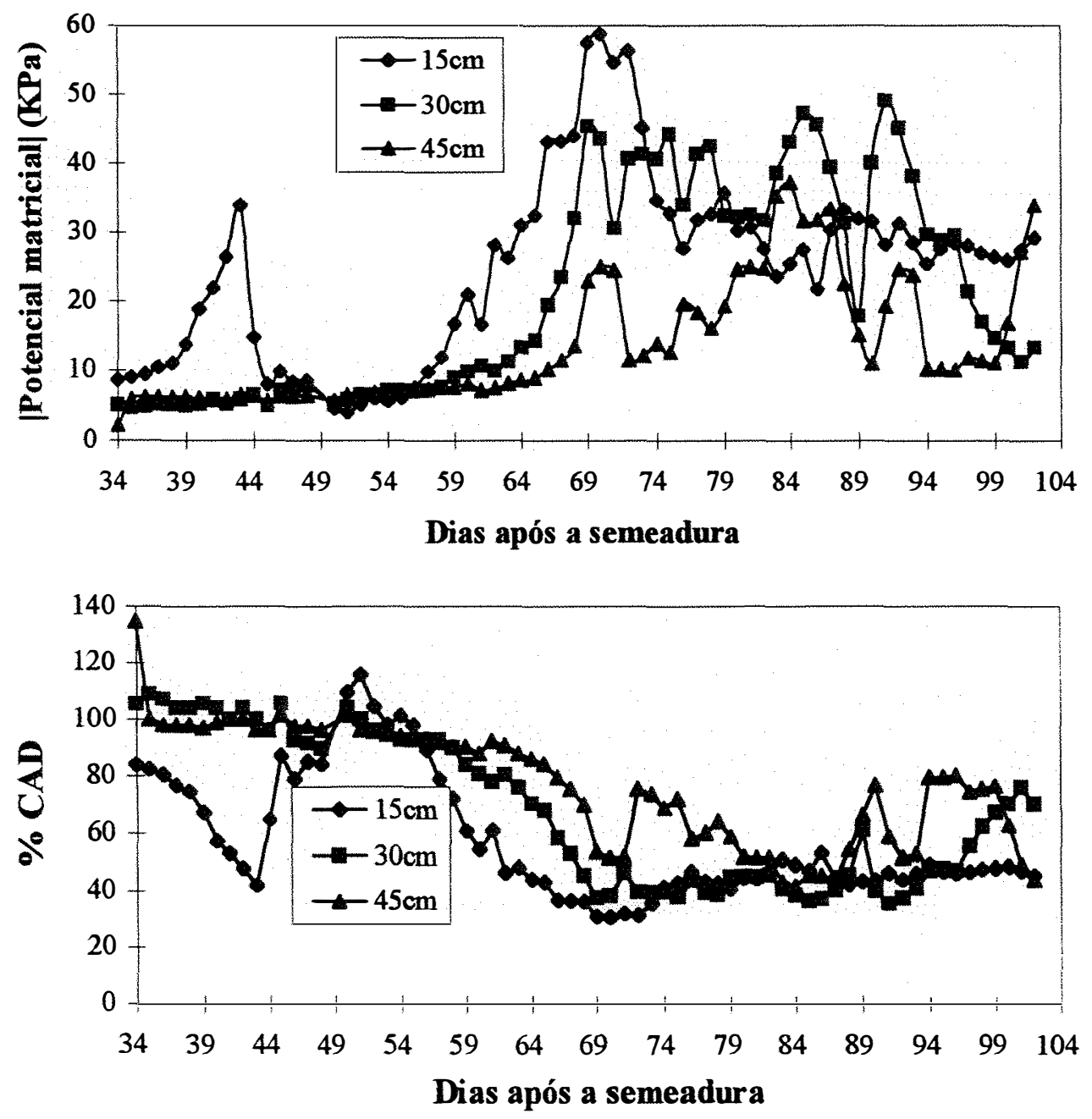

FIGURA 7 - Módulo do potencial matricial (a) e \% da CAD (b) ocorridos no Tratamento 1. 
Uma análise genérica dos diferentes gráficos pode comprovar a dificuldade de se manter um potencial matricial próximo do - $10 \mathrm{kPa}$, durante o ciclo todo da cultura. Durante a fase inicial da cultura, com um consumo de água baixo, é comum a aproximação da umidade atual a valores próximos da saturação, enquanto que na fase de frutificação, é comum que com apenas 24 horas entre uma irrigação e outra, se atinja potenciais matriciais por volta de - 40 $\mathrm{kPa}$, pois o consumo de água pelas plantas é muito intenso. Enquanto que a evapotranspiração cultural média até os 55 dias após a semeadura se manteve em torno de valores inferiores a 2,0 mm.dia ${ }^{-1}$, após esse período esta se manteve a valores médios próximos à $4 \mathrm{~mm} \cdot \mathrm{dia}^{-1}$, como mostra a Figura 3 .

Valores entre 0 e - $10 \mathrm{kPa}$ na fase final da cultura podem ser explicados não somente pela diminuição do consumo de água pelas plantas, mas também pela compactação do solo verificada, que certamente leva à uma diminuição da velocidade de infiltração da água no solo.

DOORENBOS e PRUITT (1976) sugerem um potencial matricial de manejo entre -30 e -81 kPa, enquanto MILLAR sugere - $50 \mathrm{kPa}$. Decorre, que parece não ser este somente, um bom critério de definição de irrigação.

Ao se praticar um manejo com um potencial matricial de $-45 \mathrm{kPa}$ (Figura 13), a CAD terá se esgotada em mais de $60 \%$. Se considerar que a cultura do melão pertence ao Grupo 3 e nas condições climáticas de Inha Solteira (DOORENBOS e KASSAM, 1988), tem-se uma recomendação de um esgotamento de apenas $45 \%$ da CAD. 

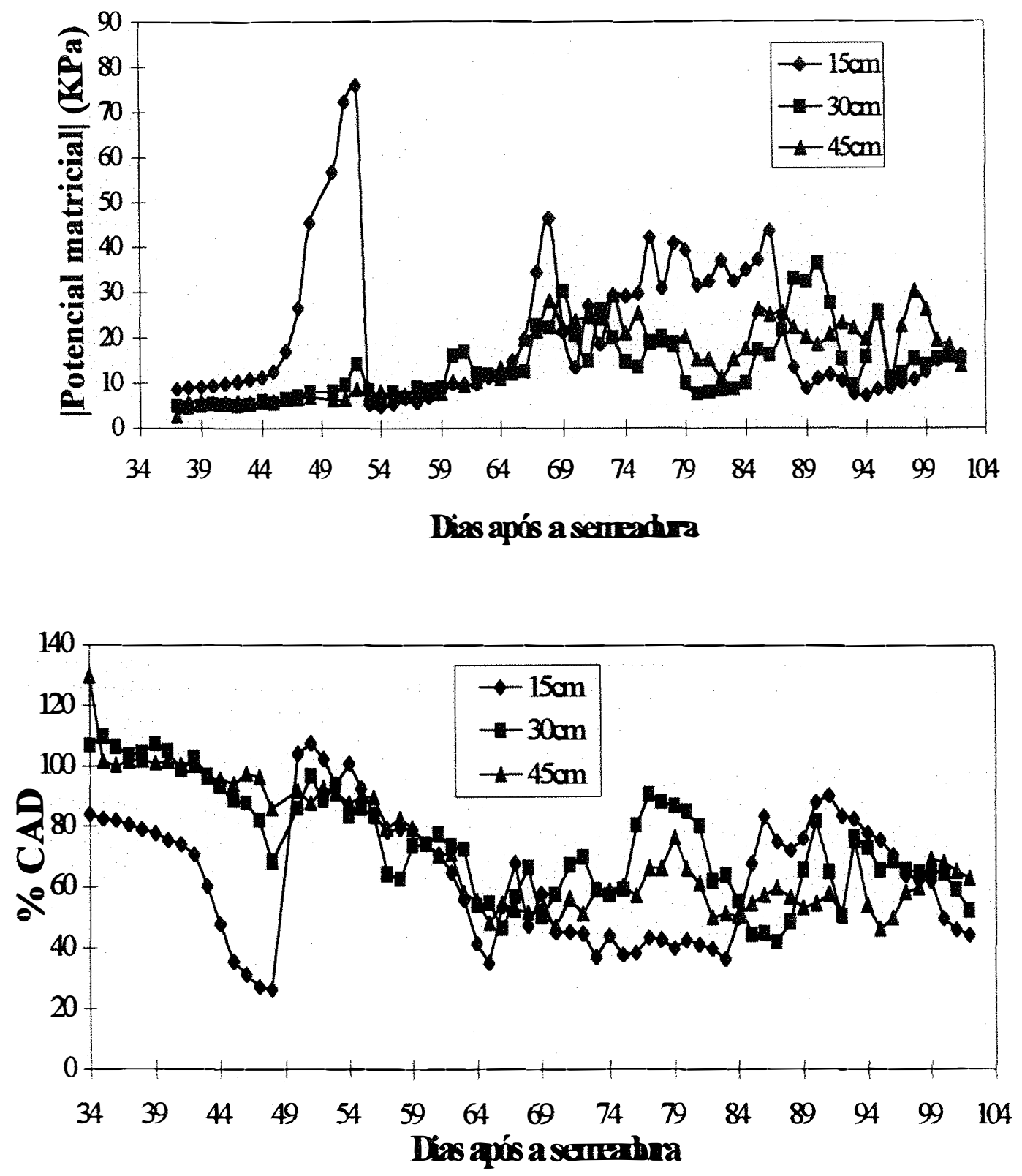

FIGURA 8 - Módulo do potencial matricial (a) e \% da CAD (b) ocorridos no Tratamento 2 .

Por outro lado, MILLAR e CHOUDHURY (1980) informam que se a cultura for mantida à potenciais matriciais de -220 e $-360 \mathrm{kPa}$, sua queda na produção seria de 10 e $20 \%$, respectivamente. Valores estes que não 
corroboram com os dados obtidos neste experimento. A manutenção da cultura na faixas citadas levaria o solo à uma reserva de água ainda menor, o que provavelmente seria traduzida em quedas de produtividades maiores do que as observadas.
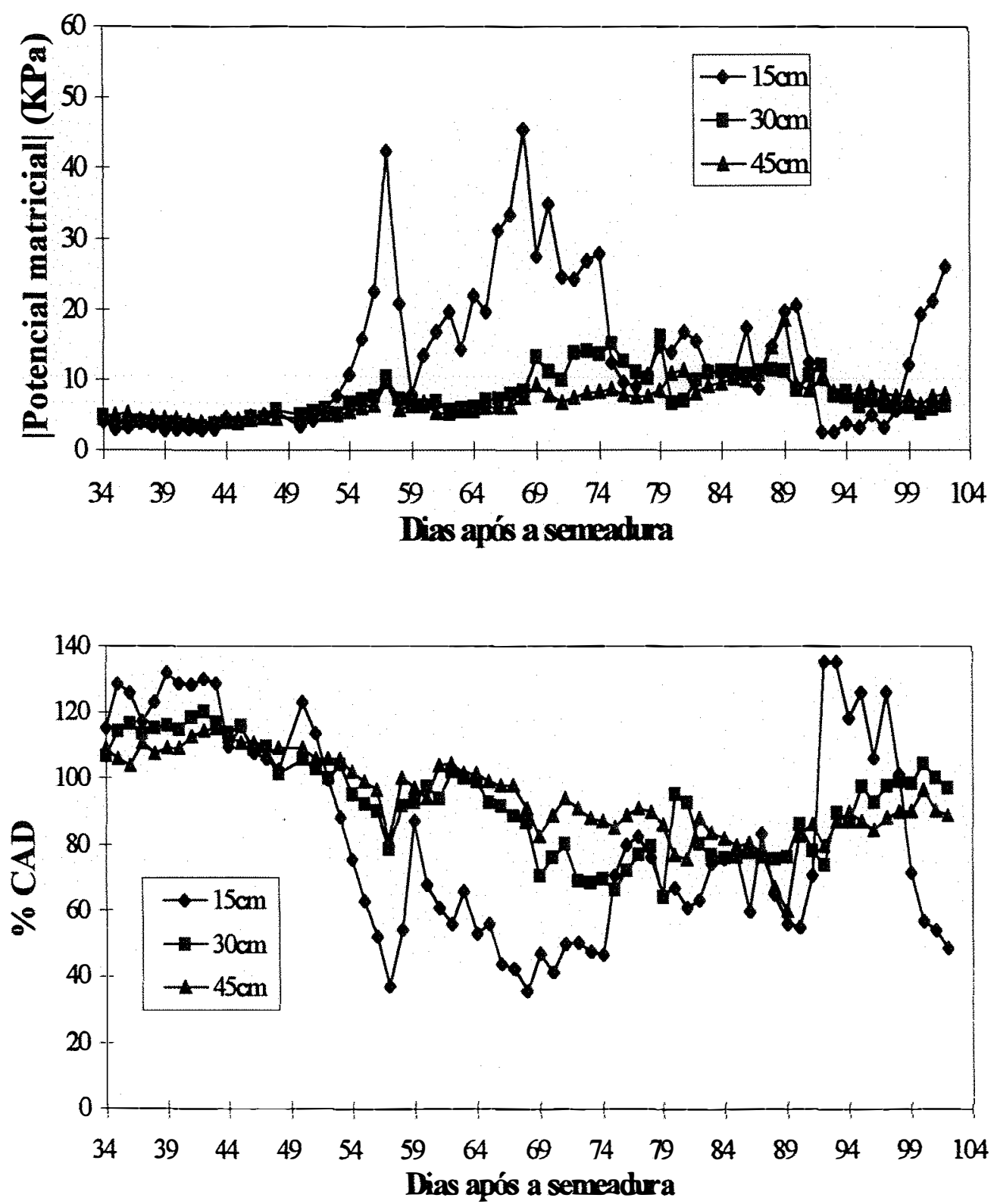

FIGURA 9 - Módulo do potencial matricial (a) e \% da CAD (b) ocorridos no Tratamento 3 

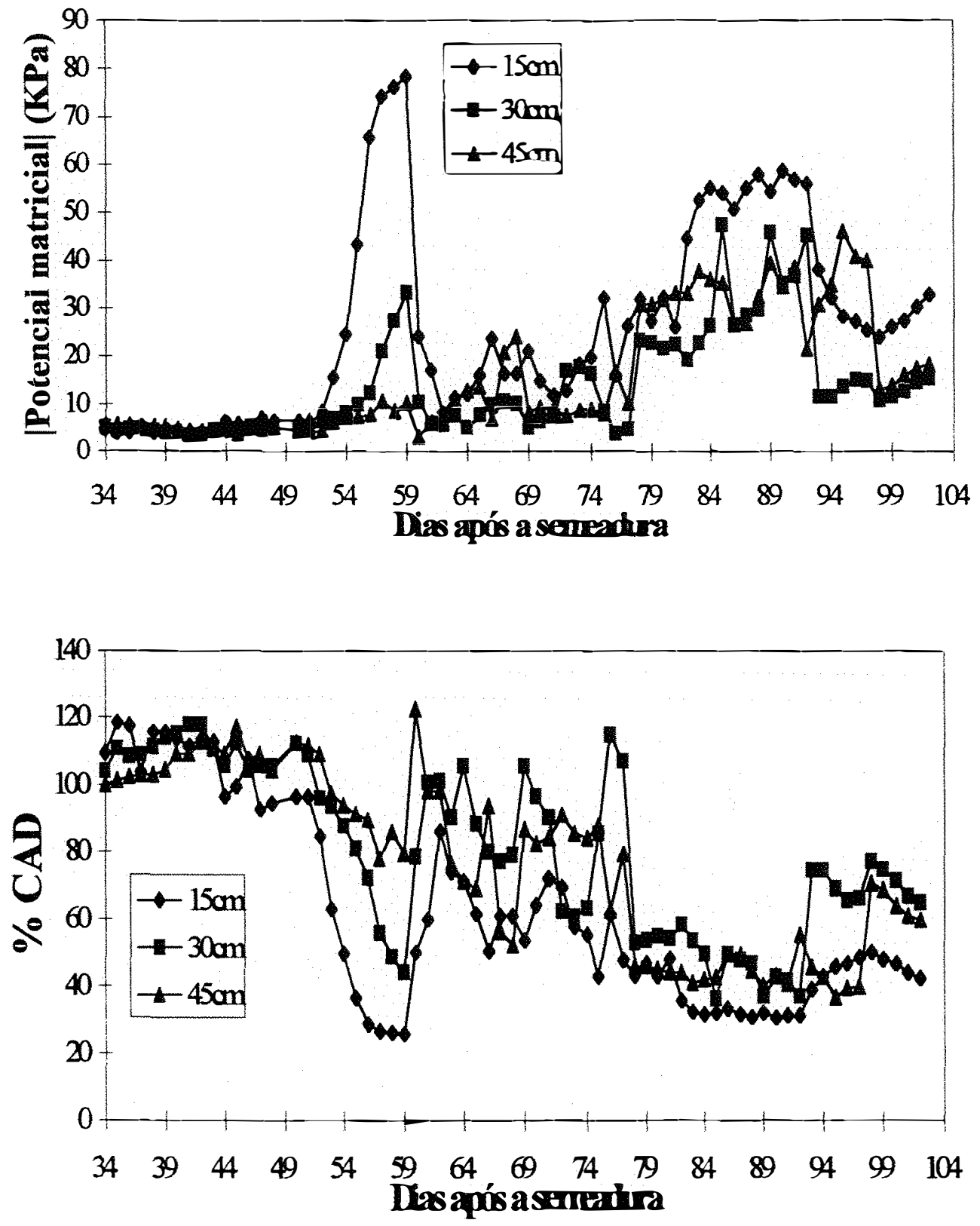

FIGURA 10 - Módulo do potencial matricial (a) e \% da CAD (b) ocorridos no Tratamento 4 . 

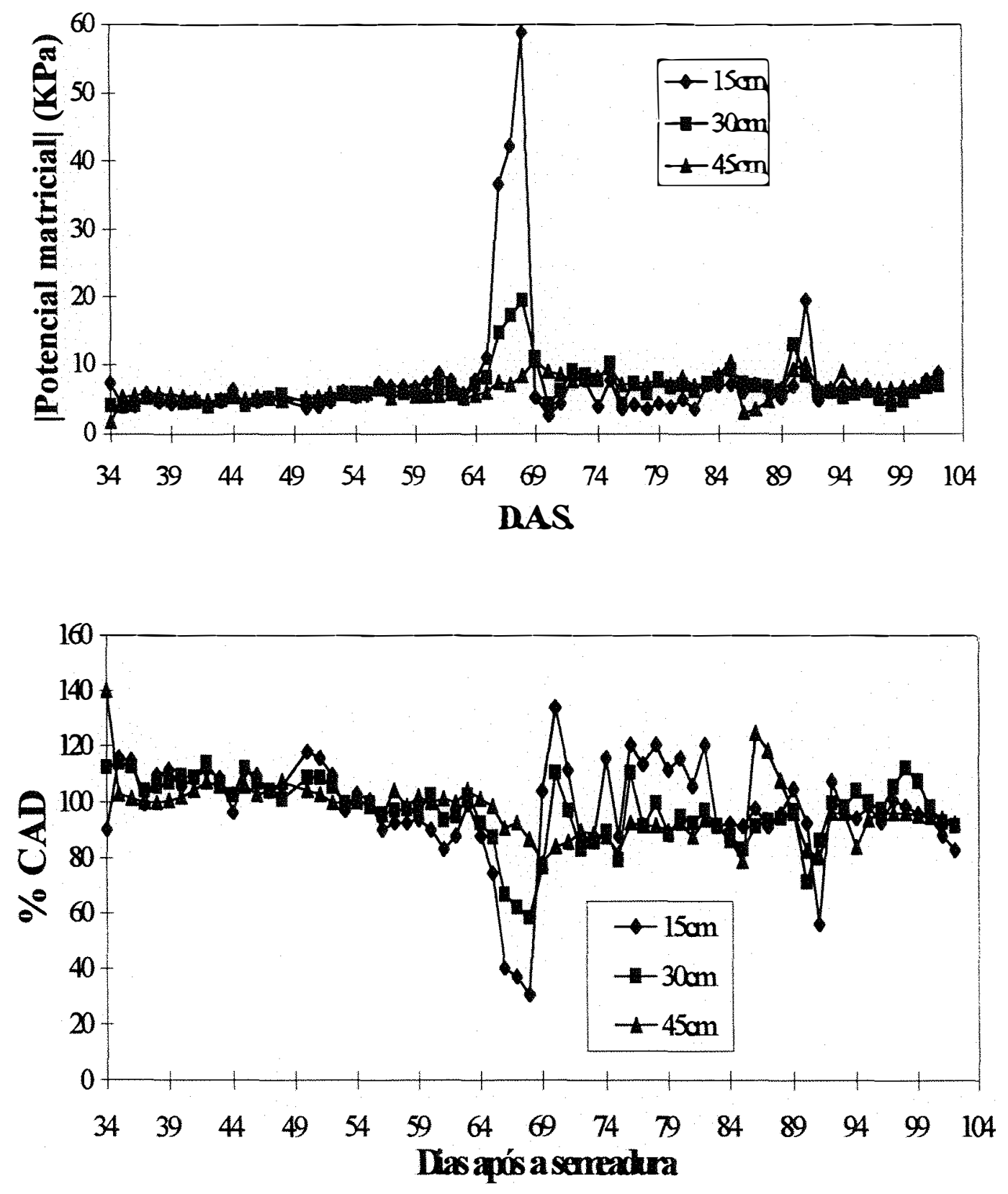

FIGURA 11 - Módulo do potencial matricial (a) e \% da CAD (b) ocorridos no Tratamento 5. 
ARAGÃO JÚNIOR et al (1991) estudaram o manejo da irrigação com base no esgotamento da $\mathrm{CAD}$. As irrigações se iniciavam todas as vezes que se observava uma CAD atual de 95,75 e $55 \%$. Com o esgotamento de $45 \%$ da $\mathrm{CAD}$, a redução na produtividade em relação à testemunha foi de $42 \%$.

Mesmo considerando que as produtividades foram muito baixas, temse que a manutenção seguida da cultura à baixas umidades pode levar a quedas de produtividades consideráveis.

Um bom manejo da irrigação deve considerar o potencial matricial e a variação da $\mathrm{CAD}$ ao longo da cultura, porém, como foi considerado neste trabalho, a extração sendo muito intensa no período da frutificação, tem-se dificuldade em manter o solo com uma umidade alta.

Na Figura 14 (a), o último dado de potencial matricial de cada curva mostra o dia em que o tensiômetro chegou ao limite de seu funcionamento. É possível perceber que existe uma predominância de extração de água nas camadas superiores, em função de uma maior massa de raízes (Quadro 10) nestas camadas.

Verifica-se que o intervalo de dias entre o "estouro" do tensiômetro instalado à 15 e 30 centímetros é diferente do intervalo entre os tensiômetros instalados à 30 e 45 centímetros, mais uma vez indicando a extração de água maior nas camadas de solo superiores, reflexo de uma maior massa de raízes. 


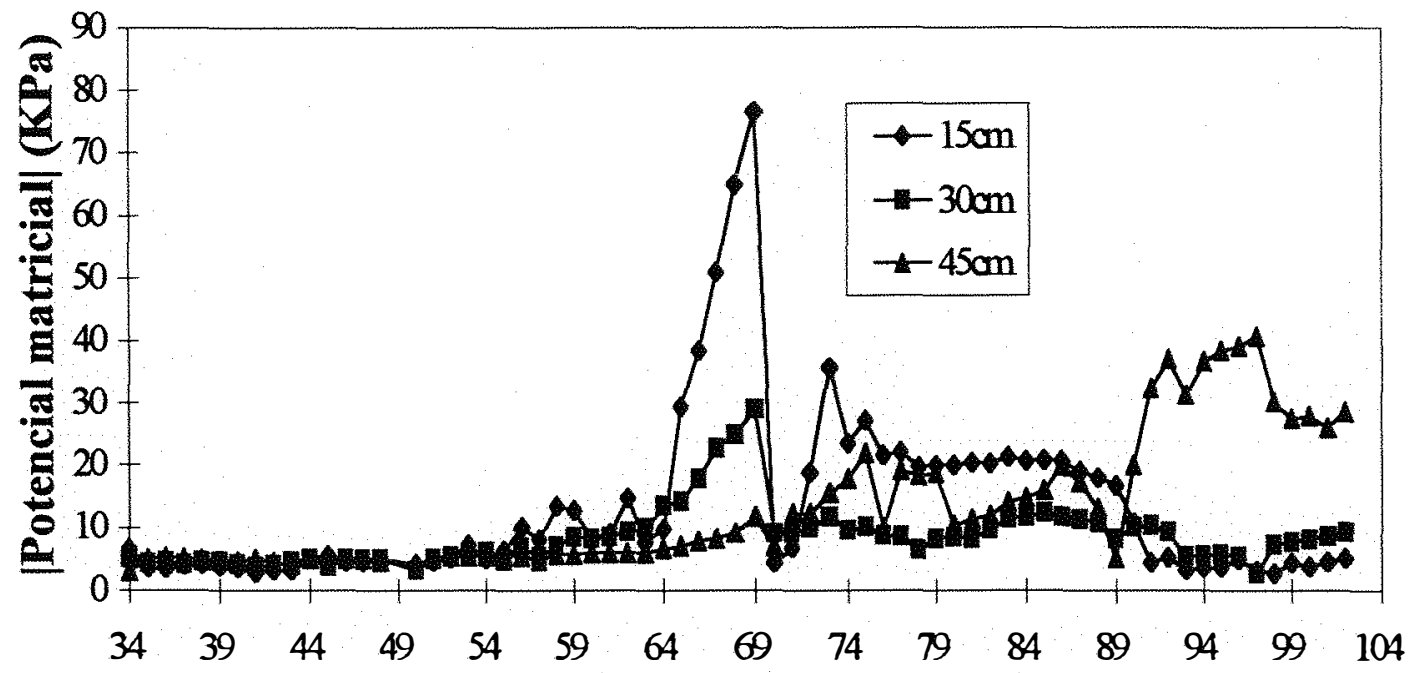

Dias após a semeadra

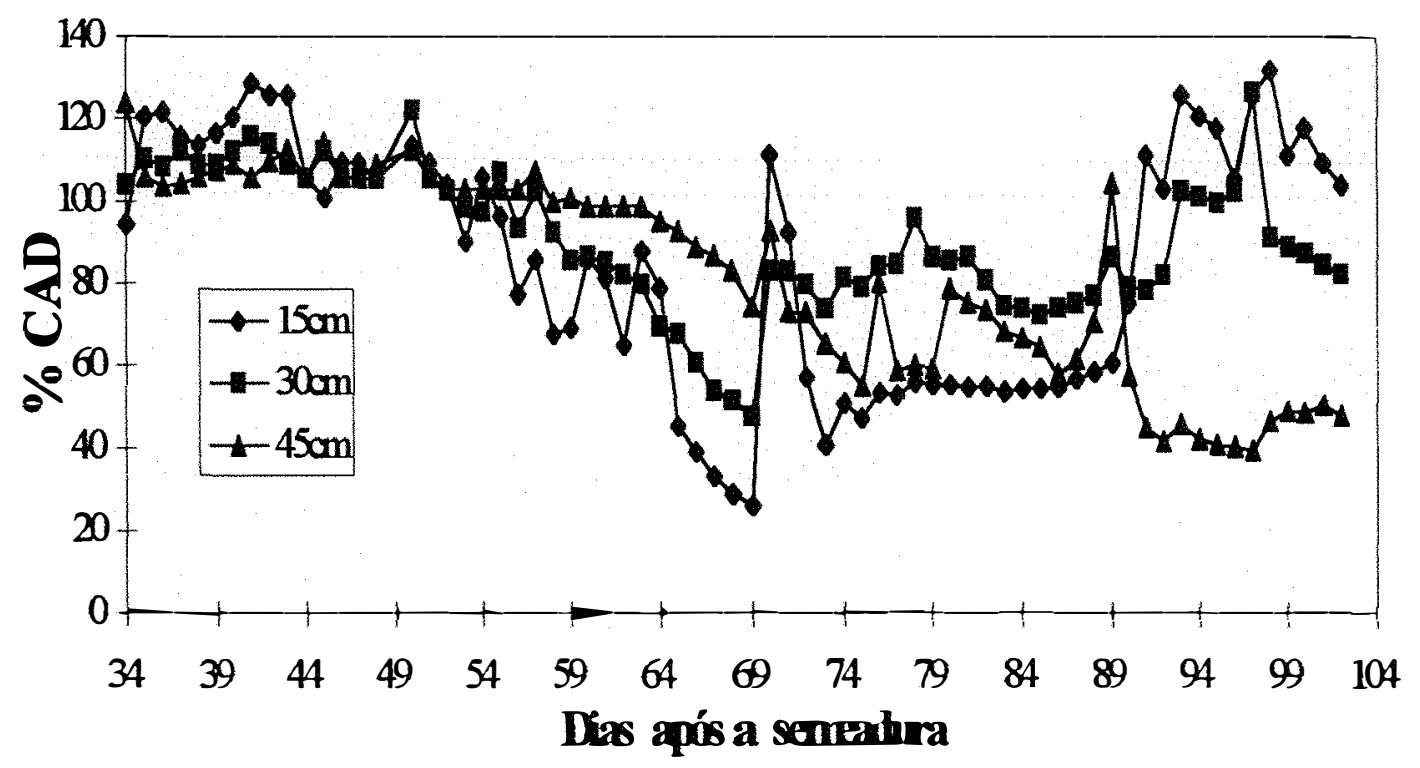

FIGURA 12 - Módulo do potencial matricial (a) e \% da CAD (b) ocorridos no Tratamento 6 . 

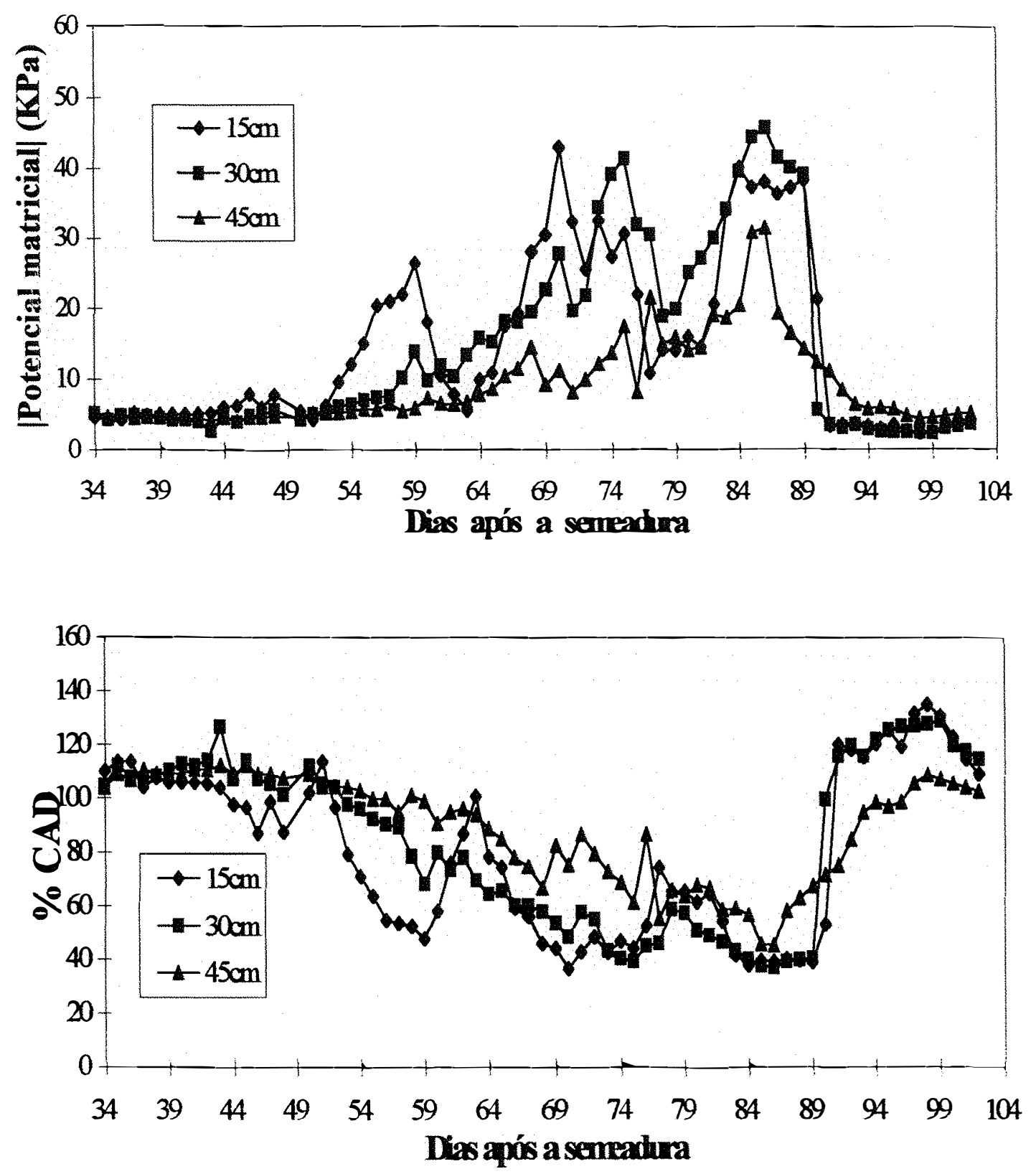

FIGURA 13 - Módulo do potencial matricial (a) e \% da CAD (b) ocorridos no Tratamento 7. 

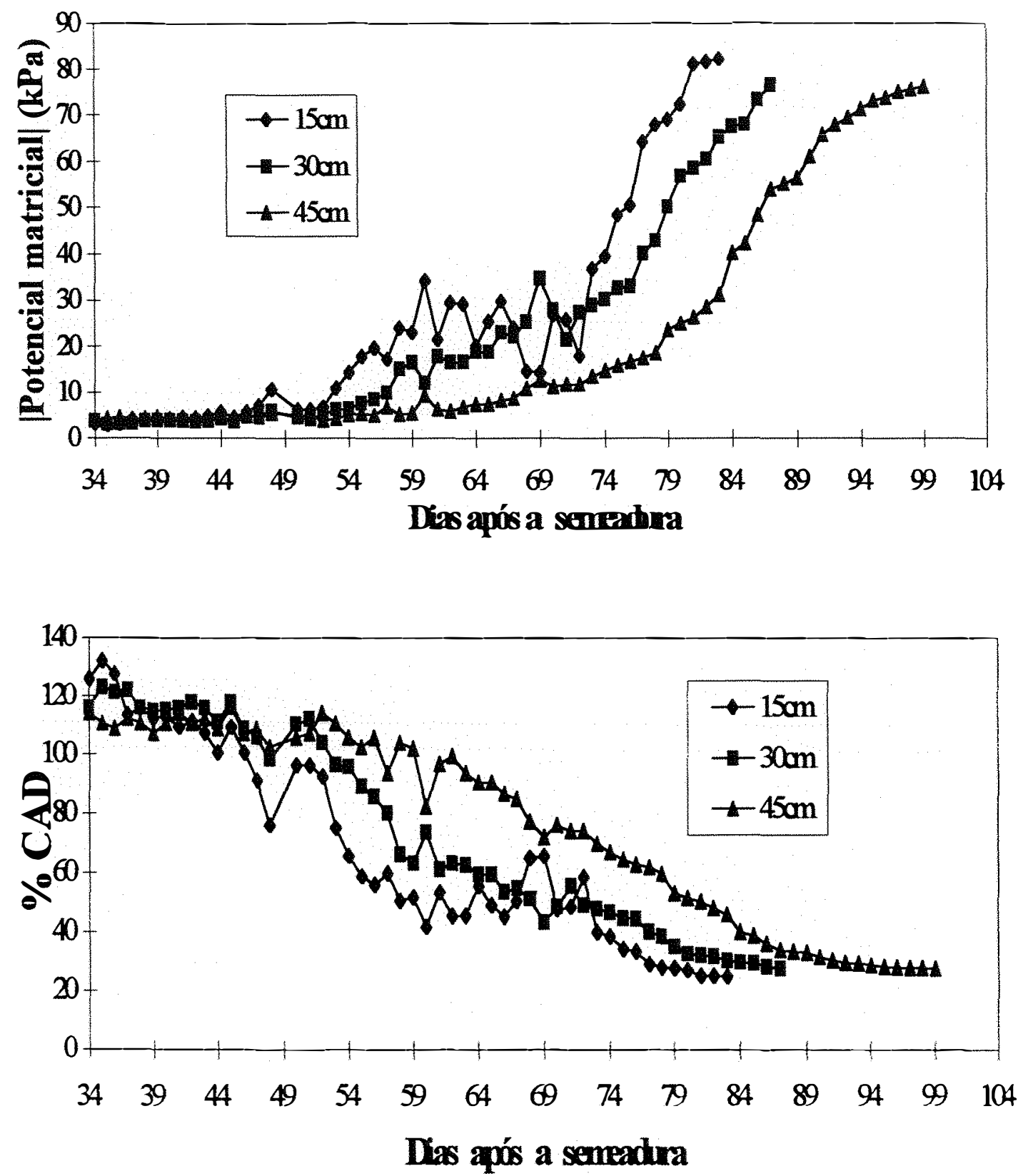

FIGURA 14 - Módulo do potencial matricial (a) e \% da CAD (b) ocorridos no Tratamento 8. 


\subsection{Crescimento de raízes}

A distribuição percentual da massa de raízes do meloeiro pode ser observada no Quadro 10.

A maior distribuição das raízes na camada entre a superficie e 10 centímetros sinaliza para a necessidade de irrigacoões em pequenos espaços de tempo. A leitura da distribuição das raízes com os valores baixos da $\mathrm{CAD}$ durante a fase de frutificação da cultura pode levar a sugestão de que, nesta fase as imigações poderiam ser realizadas em duas vezes ao dia, de modo que as plantas tenham um perfeito suprimento hídrico, uma vez que neste período não se venificam potenciais matriciais que levariam o solo à uma condição próxima da saturação.

MACGILLIVRAI (1951) estudando os efeitos da imigação sobre a cultura do melão, observou que o crescimento de raízes não apresentou diferenças entre os tratamentos empregados.

QUADRO 10 - Distribuição percentual das raízes do meloeiro em condições de imigação por gotejamento.

\begin{tabular}{|c|c|c|c|}
\hline \multirow{2}{*}{ TRATAMENTO } & \multicolumn{3}{|c|}{ "DISTRIBUIÇÃO DE RAIZZES (\%) } \\
\hline & $00-10 \mathrm{~cm}$ & $10-20 \mathrm{~cm}$ & $20-30 \mathrm{~cm}$ \\
\hline 1 & 78,18 & 15,11 & $\overline{6,71}$ \\
\hline 2 & 81,37 & 11,82 & 6,82 \\
\hline 3 & 82,47 & 9,10 & $\overline{8,44}$ \\
\hline 4 & 79,45 & 10,89 & 9,66 \\
\hline 5 & 80,61 & 12,56 & 6,83 \\
\hline 6 & 84,03 & 12,77 & 3,20 \\
\hline 7 & 80,84 & 12,86 & 6,29 \\
\hline 8 & 81,65 & 9,92 & 8,43 \\
\hline
\end{tabular}


MAROUELLI et al (1994) mostra que as raízes do meloeiro podem assumir profundidades que variam entre 50 e 120 centímetros. $\mathrm{O}$ que não foi a realidade desse experimento. A concentração das raízes na camada superficial do solo se deve provavelmente ao tipo de sistema de imigação e a compactação do terreno. Se a cultura for imigada por aspersão, provavelmente se terá outro perfil de distribuição de raízes, porém, seguramente não atingirá a profundidade citada

De acordo com TAYLOR e ARKIN (1981) os sintomas de falta de umidade na zona das raízes são os mais facilmente discerníveis em uma cultura. São percebidos pelo murchamento e/ou enrolamento e às vezes escurecimento ou ressecamento das folhas. Segundo esses autores, estes sintomas aparecem quando a planta está inapta para obter água suficiente do solo para transpirar à sua taxa potencial (ao nível normal) e ainda, a produção de biomassa irá reduzir quando a transpiração também o for reduzida.

No entanto, para as condições climáticas de Ilha Solteira, e mesmo quando a irigação está sendo feita dentro dos criténos e sem supressão hídrica, observa-se um murchamento das folhas entre 11 e 15 horas sem que se obtenha produtividades consideradas baixas, que comprometeria o investimento. Estas tornam-se túrgidas novamente ao final da tarde e no período da manhã. Provavelmente este fato ocorra pela alta concentração das raízes na camada superficial do solo e pela alta radiação incidente. Após o período de intensa absorção de água pelas plantas, provavelmente haja um equilíbrio entre a 
capacidade potencial de absorção e as necessidades reais da cultura, promovendo uma turgidez adequada às plantas.

Todas as informações reunidas neste experimento, leva novamente a conclusão de que, para as condições climáticas de Ilha Solteira, a prática de duas irrigaş̃es ao dia, provavelmente possa reverter ou amenizar esse quadro.

\subsection{Custo de produção por hectare}

O custo de produção e a receita da cultura foram levantados e os dados obtidos no Tratamento 7 (testemunha) podem ser verificados no Quadro 11.

O custo de produção por hectare da cultura (Tratamento 7) ficou em US\$ 2.202,96, para uma receita líquida de US\$ $16.702,64$. O custo da energia necessária para a imigação representou apenas $1,9 \%$ do custo total de produção, devido ao sistema de irrigação utilizado, que não requer grandes alturas manométricas para sua operação, bem como pelo fato de que a cultura se utiliza de uma quantidade muito grande de defensivos agrícola, que possuem um alto valor de mercado.

Os resultados obtidos mostram grandes diferenças entre os obtidos por PAULINO et al (1994), que para a produção de um hectare de melão obtiveram um custo de produção de US\$ 2.392,29 e uma receita líquida de US\$ 4.247,96. Nos dois casos, os custos de produção vislumbram a comercialização a granel, portanto, não contemplam o custo de aquisição de embalagem, que assume um 
custo relativamente alto. Porém, em função da destinação que for dada aos frutos após a colheita, as embalagens deverão fazer parte do custo de produção.

Outro fator de grande importância na remuneração ao produtor é a época de comercialização do produto, como destaca PAULINO et al (1994), que faz uma análise da variação estacional de preços e também a variação da quantidade comercializada no CEAGESP no período de 1986 a 1991.

No Quadro 12 pode ser observado a análise econômica comparativa entre os tratamentos empregados. Os fatores de variação são o tempo de irrigação, na parte de custos de produção e na receita bruta, tem-se variações em função das produtividades obtidas nos diferentes tratamentos.

O Quadro 12 mostra que neste caso (irrigação por gotejamento), a economia de energia em si, não assume grande importância do ponto de vista econômico no custo de produção, pois se trabalha com conjuntos moto-bomba de baixa potência. No entanto, o controle e o perfeito fomecimento de água às plantas traz grande reflexo na produtividade da cultura, o que faz a diferença econômica entre os tratamentos. O provável excesso de água na fase inicial da cultura (Tratamento 7) promoveu uma menor produção de frutos, se comparado com os Tratamentos 1 e 2 . Assim, estes acabaram por promover um aumento de renda líquida entre 46 e $42 \%$.

O raciocínio da compensação entre a supressão hídrica, consumo de energia e produtividade podem ser visto no Tratamento 8 , que utilizou $38,5 \%$ menos energia que o Tratamento 7 e produziu uma receita $13,1 \%$ superior. 
QUADRO 11 - Estimativa de custo de produção e receita em um hectare de melão, cv. Valenciano Amarelo, na região de Illa Solteira, SP. Dados relativos ao Tratamento 7 (testemunha).

\begin{tabular}{|c|c|c|c|c|}
\hline 1. Operação Mecânica & $\begin{array}{l}\text { Uni- } \\
\text { dade }\end{array}$ & $\begin{array}{c}\text { Coeficiente } \\
\text { Técnico }\end{array}$ & $\begin{array}{c}\text { Valor unitánio } \\
\text { (US\$) }\end{array}$ & $\begin{array}{c}\text { TOTAL } \\
\text { (USS) }\end{array}$ \\
\hline Aração & H.M.* & 3,0 & 5,88 & 17,63 \\
\hline Sulcador & H.M. & 3,0 & 5,58 & 16,74 \\
\hline Gradagem & H.M. & 1,5 & 6,39 & 9,59 \\
\hline Pulveriz (16x) & H.D. & 8,0 & 9,10 & 72,80 \\
\hline Irrigação & $\mathrm{kw} \cdot \mathrm{h}$ & 558,23 & 0,0733 & 40,92 \\
\hline \multirow{2}{*}{\multicolumn{2}{|c|}{ Sub. Total }} & 7,0 & 4,95 & 34,65 \\
\hline & & & & 192,33 \\
\hline \multicolumn{5}{|l|}{ 2. Operação Manual } \\
\hline Semeadura & H.D. & 2,0 & 9,10 & 18,20 \\
\hline Desbaste & H.D. & 2,0 & 9,10 & 18,20 \\
\hline Replantio & H.D. & 1,0 & 9,10 & 9,10 \\
\hline Capinas & H.D. & 24,0 & 9,10 & 218,40 \\
\hline Colheita & H.D. & 12,0 & 9,10 & 109,20 \\
\hline $\begin{array}{c}\text { Classificação e Carregamento } \\
\text { Sub. Total }\end{array}$ & H.D. & 12,0 & 9,10 & $\begin{array}{l}109,20 \\
\mathbf{4 8 2 , 3 0}\end{array}$ \\
\hline \multicolumn{5}{|l|}{ 3. Insumos } \\
\hline Arrivo $(2 x)$ & litro & 0,12 & 28,72 & 3,45 \\
\hline Benlate (5x) & kilo & 1,4 & 24,47 & 34,25 \\
\hline Dithane (3x) & kilo & 2,4 & 4,61 & 11,06 \\
\hline Cerconil (6x) & kilo & 4,8 & 19,22 & 92,26 \\
\hline Daconil (2x) & kilo & 1,6 & 19,73 & 29,97 \\
\hline $\operatorname{Decis}(5 \mathrm{x})$ & litro & 0,6 & 26,33 & 15,80 \\
\hline Dipterex (3x) & litro & 3,6 & 7,12 & 25,63 \\
\hline Furadan 350 TS & litro & 0,01 & 101,78 & 1,02 \\
\hline Tamaron $(5 x)$ & litro & 2,0 & 9,88 & 19,76 \\
\hline Vertimec $(1 \mathrm{x})$ & litro & 0,53 & 114,37 & 60,62 \\
\hline Semente & kilo & 1,0 & 38,80 & 38,80 \\
\hline Adubo $06-30-00$ & kilo & 365 & 0,252 & 91,98 \\
\hline Cloreto de potássio & kilo & 115 & 0,320 & 36,80 \\
\hline Uram & kilo & 208 & 0,233 & 48,46 \\
\hline \multicolumn{4}{|l|}{ Sub-Total } & 509,86 \\
\hline 4. Juros Bancários ** & & & & 17,77 \\
\hline 5. Depreciação $* \star \star$ & & & $800, \overline{70}$ & 800,70 \\
\hline CUSTO DE PRODUCÃ Ấ & & & & $2.002,96$ \\
\hline RECEITA BRUTA & caixas & 1.732 & 10,80 & $18.705,60$ \\
\hline RECEITA LIQUIDA & & & & $16.702,64$ \\
\hline
\end{tabular}

${ }^{*}$ H.M.: Horas - máquinas e H.D.: Homens - dia.

** Corresponde a $6 \%$ ao ano sobre o capital próprio aplicado nas despesas operacionais com insumos, preparo do solo, plantio e adubação, tratos culturais, colheita e transporte durante 3 meses.

*** Considerou-se uma vida útil do equipamento de irrigação de 6 anos, com depreciação linear, considerando o valor final igual zero. 
Outro fato a ser considerado, é o de que o sistema de irrigacão projetado estará imigando um setor por vez, portanto, o sistema de bombeamento não será compartilhado com outros setores, fato perfeitamente possível, uma vez que foi projetado de modo a funcionar 3 horas e vinte minutos por dia.

Assim, o custo do sistema de irrigação em uma eventual ampliação de área, ficaria em valores inferiores aos apresentados (custo do projeto por unidade de área), possibilitando uma maior receita líquida ao produtor.

Os resultados mostram que o período crítico de formecimento de água à cultura é a frutificação, porém o excesso de água na fase inicial deve ser estudado mais atentamente. Pesquisas com lisímetros para quantificar e calibrar os parâmetros hídricos $(\mathrm{ETo}, \mathrm{Kc})$ da cultura devem ser incentivadas.

QUADRO 12 - Análise comparativa do consumo de água, energia e análise econômica da produção de um hectare de melão.

\begin{tabular}{|c|c|c|c|c|c|c|c|}
\hline $\begin{array}{l}\text { TRATA- } \\
\text { MENTOS }\end{array}$ & $\begin{array}{c}\text { ENER- } \\
\text { GIA } \\
\text { Kw.h }\end{array}$ & $\begin{array}{c}\text { Água } \\
\text { aplicada } \\
\mathbf{m}^{3} / \mathbf{h a}\end{array}$ & $\begin{array}{l}\text { e.u.a.* } \\
\mathrm{kg} / \mathrm{m}^{3}\end{array}$ & $\begin{array}{l}\text { Custo da } \\
\text { energia } \\
\text { USS }\end{array}$ & $\begin{array}{l}\text { Custo de } \\
\text { produção } \\
\text { USS }\end{array}$ & $\begin{array}{c}\text { RECEITA } \\
\text { BRUTA } \\
\text { USS }\end{array}$ & $\begin{array}{c}\text { RECEITA } \\
\text { LÍQUIDA } \\
\text { USS }\end{array}$ \\
\hline 1 & 522,95 & $2.182,24$ & 14,10 & 38,37 & $2.000,37$ & $25.552,80$ & $22,552,43$ \\
\hline Relativa (\%) & 93,7 & 91,3 & 149,7 & 93,7 & 100,0 & 136,6 & 145,8 \\
\hline 2 & 504,95 & $2.107,62$ & 14,67 & 37,05 & $1.999,03$ & $25.682,48$ & $23.683,45$ \\
\hline Relativa (\%) & 90,5 & 88,2 & 155,7 & 90,5 & 99,8 & 137,3 & 141,8 \\
\hline 3 & 519,28 & $2.166,12$ & 10,19 & 38,10 & $2.000,1$ & $18.327,60$ & $16.327,50$ \\
\hline Relativa (\%) & 93,0 & 90,6 & 108,1 & 93,0 & 99,9 & 98,0 & 97,8 \\
\hline 4 & 495,39 & $2.066,38$ & 10,28 & 36,35 & $1.998,32$ & $17.647,21$ & $15.648,89$ \\
\hline Relativa (\%) & 88,7 & 86,4 & 109,1 & 88,8 & 99,8 & 94,3 & 93,7 \\
\hline 5 & 519,65 & $2.169,00$ & 8,18 & 38,13 & $2.000,13$ & $14.731,26$ & $12.731,13$ \\
\hline Relativa (\%) & 93,1 & 90,7 & 86,8 & 93,1 & 99,9 & 78,8 & 76,2 \\
\hline 6 & 513,03 & $2.141,09$ & 8,03 & 37,64 & $1.999,63$ & $14.288,41$ & $12.288,78$ \\
\hline Relativa (\%) & 91,9 & 89,6 & 85,3 & 91,9 & 99,8 & 76,4 & 73,6 \\
\hline 7 & 558,23 & $2.390,79$ & 9,42 & 40,96 & $2.202,96$ & $18.705,63$ & $16 . \overline{702,67}$ \\
\hline Relativa (\%) & 100 & 100 & 100 & 100 & 100 & 100 & 100 \\
\hline 8 & 343,61 & $1.433,32$ & 17,53 & 25,21 & $1.987,02$ & $20.876,48$ & $18.889,46$ \\
\hline Relativa (\%) & 61,55 & 60,0 & 186,1 & 61,6 & 99,2 & 111,6 & 113,1 \\
\hline
\end{tabular}


Do ponto de vista de eficiência no uso da água, o tratamento que melhor converteu água em frutos foi o 8, resultado do corte da irrigação aos 75 dias após a semeadura. RITSCHEL et al (1994) não encontraram diferenças estatisticamente significativas para a produtividade quando a irrigação foi cessada aos 56, 63 e 70 dias. No entanto na melhor conversão água - matéria (e.u.a.), este valor ficou em 19,82 kilos de melão por metro cúbico de água aplicada, contra 17,53 obtidos no Tratamento 8. 


\section{CONCLUSÕES}

Diante dos resultados obtidos e para as condições em que foram desenvolvidos este experimento, pode-se concluir que:

a. A produtividade de frutos foi afetada pela supressão hídrica aplicada à cultura do melão e em diferentes fases fenológicas;

b. A supressão hídrica entre 31 e 48 dias após a semeadura (com $\psi_{\mathrm{m}}$ mínimo de $-76,1 \mathrm{kPa}$ ) promoveu a maior produtividade, $30.918 \mathrm{~kg} / \mathrm{ha}$;

c. O corte da irigação aos 75 dias após a semeadura pode ser aplicado na cultura, pois não resultou em queda significativa de produtividades;

d. O uso da imigação por gotejamento na cultura do melão produziu uma concentração média de $80 \%$ das raízes na camada de 0 a 10 centímetros de solo;

e. As altas produtividades obtidas, os frutos com boas características qualitativas e as receitas obtidas com a cultura do melão, qualificam a região de Tha Solteira como apta para a sua produção, sendo esta uma opção na diversificação agrícola regional. 


\section{REFERÊNCIAS BIBLIOGRÁFICAS}

ABREU, T.A. de; OLITTA, A.F.L.; MARCHETTI, D.A.B. Comparação dos métodos de irrigação por sulco e por gotejo na cultura do melão, no Vale do São Francisco. Pesquisa Agropecuária Brasileira, Brasilia, 13(3):35-45, 1978.

ARAGÃO JÚNIOR, T.C.; MAGALHÃES, C.A; SANTOS, C.S.V. Efeitos de níveis de umidade no solo em cultivares de melão (Cucumis melo L.). Fortaleza, EPACE, 1991. 16p. (Boletim de Pesquisa, 16).

AULEUBACH, B.B. \& WORTHINGTON, J.T. Sensory evaluation of muskmelon: is soluble solids content a good quality index. Hortscience, St. Joseph, 9(2): 136-37, 1974.

BARRET, J.W. \& SKOGERBOE, G.V. Crop production functions and the allocation and use of irrigation water. Agricultural Water Management, Amsterdam, 3: 53-64, 1980.

BATTIKHI, AM \& HILL, RW. Inigation scheduling and cantaloupe yield model for the Jordan Valley. Agricultural Water Management, Amsterdam, 15: 177-187, 1988. 
BEDUM, J.A.D.; HERNANDEZ, F.B.T.; SUZUKI, MA; JAVAREZ JÚNIOR, A; BUZETTI, S. Efeito de lâminas de irrigação sobre os principais parâmetros produtivos do meloeiro na região de Ilha Solteira - SP. CONGRESSO BRASILEIRO DE ENGENHARIA AGRÍCOLA, 22., Anais. Ihéus, SBEA, 1993. v.4, p.2.390-400.

BEDUM, J.A.D. Viabilidade da cultura do milho (Zea mays L.) irrigado por gotejamento, em rotação com a cultura do melão, utilizando dois métodos de aplicação de fertilizantes, dois coeficientes de cultivo, em duas populações de plantas. Itha Solteira, 1995, 63p. (Graduação - Faculdade de Engenharia de Iha Solteira - UNESP).

BEGG, J.E. \& TURNER, N.C. Crop water deficits. Advances in Agronomy, New York, 28:61-217, 1976.

BELFORT, C.C.; HAAG, H.P.; MATSUMOTO, T.; CARMELLO, Q.A.C.; SANTOS, J.W.C. Nutrição mineral de hortaliças. LXX. Acumulação de matéria seca e recrutamento de macronutrientes pelo melão (Cucumis melo L. cv. Valenciano Amarelo CAC) cultivado em Latossolo Vermelho Amarelo, em Presidente Venceslau, SP. Anais da Escola Superior de Agricultura “Luiz de Queiroz”, Piracicaba, 43:159-218, 1986.

BERNARDI, J.B. Instruções práticas: a cultura do melão. Campinas, Instituto Agronômico, 1974. (IAC. Boletim Informativo, v.26, t. 2).

BRESLER, E. Trickle-drip irrigation: principles and aplication to soil water management. Advances in Agronomy, New York, 29:344-93, 1977. 
BUZETTI, S.; HERNANDEZ, F.B.T.; SÁ, ME.; SUZUKI, M.A. Influência da adubação nitrogenada e potássica na eficiência do uso da água e na qualidade de frutos de melão. Scientia Agricola, Piracicaba, 50(2):419-26, 1993.

CALEGAR, G.M. \& COELHO, MB. Considerações econômicas dos métodos de irrigação por gotejamento e por sulco na cultura do melão. Petrolina, EMBRAPA/CPATSA. 1987. 11p.

CARVALHO, M P. \& MELLO, L.MM. de. Classificação da capacidade de uso da terra do antigo pomar da Fazenda de Ensino e Pesquisa da Faculdade de Engenharia de Ilha Solteira - FEIS/UNESP. Tha Solteira, UNESP/FEIS, 1989. 46p.

CEAGESP. BOLETIM INFORMATIVO MENSAL, São Paulo, nov., 1994. 106p.

CODEVASF. Frutas brasileiras: exportação. Brasilia, CODEVASF, 1989. $352 p$.

COELHO, M.B.; OLITTA, A.F.L.; ARAÚJO, J.P. Influência dos métodos de irrigação por sulco e gotejo na cultura do melão. Petrolina, EMBRAPA/CPATSA, 1977. 18p.

COSTA, J.E.S. Análise fisico-química do melão produzido em condições de casa de vegetação e irrigado pelos sistemas de jato-pulsante e gotejamento. Jaboticabal, 1987. 65p. (Graduação - Faculdade de Ciências Agrárias e Veterinárias ( UNESP). 
DAN, C. Influence of different amounts of irrigation-water, irrigation-intervals on the yield and quantity of drip-irrigated musk and water melons. In: INTERNATIONAL DRIP IRRIGATION CONGRESS, 2., San Diego, 1994. Proceedings. San Diego, 1994. p. 425-30.

DAVIS Jr., R.M \& SCHWEERS, V.H. Associations between physical soil properties and soluble solids in cantaloupes. Journal of American Society for Horticultural Sciences, Davis, 96(2):213-17, 1971.

DOORENBOS, J. \& KASSAM, A.H. Efectos del agua sobre el rendimiento de los cultivos. Roma, FAO, 1988. 212p. (FAO. Boletin, 33).

DOORENBOS, J.\& PRUITT, 'W.O. Las necesidades de agua de los cultivos. Roma, FAO, 1976. 194p. (FAO. Boletin, 24).

DUSI, AN. Melão para exportação: aspectos técnicos da produção. Brasilia, DENACOOP/FRUPEX, 1992. 32p. (DENACOOP. Série Publicações Técnicas, 1).

EMPRESA BRASILEIRA DE PESQUISA AGROPECUÁRIA. Área irrigada, produção e produtividade das principais hortaliças no Brasil -1985/1986. Brasília, EMBRAPA/CNPH, 1989. 62p. (EMBRAPA/CNPH. Documentos, 4).

ENGLISH, M. Deficit irrigation. I: analytical framework. Journal of Irrigation and Drainage Engineering, New York, 116(3):399-412, 1990. 
ENGLISH, M; JAMES, L.; CHEN, C. Deficit irigation. II: observations in Columbia Basin. Journal of Irrigation and Drainage Engineering, New York, 116(3):413-426, 1990.

ERMLAND JÚNIOR, F.K.V. Efeito do cultivo em casa de vegetação com cobertura de filme de polietileno, sobre a qualidade tecnológica e conservação pós-colheita de melão (Cucumis melo L.) cv. "Valenciano Amarelo CAC", com uso da imigação por jato-pulsante. Jaboticabal, 1986. 55p. (Graduação - Faculdade de Ciências Agránas e Veterinánias / UNESP)

FERREIRA, F.A.; PEDROSA, J.F.; ALVARENGA, M.A.R Melão: cultivares e métodos culturais. Informe Agropecuário, Belo Horizonte, 8(85):26-8, 1982.

FILGUEIRA, F.A.R Manual de olericultura: cultura e comercialização de hortaliças. 2. ed. São Paulo, Editora Ceres, 1981. V.1, 338p.

FINEPLAST - Indústria e Comércio de Laminados Plásticos Ltda. Catálogo Técnico. Guanulhos, 3p. s.d.

FRIZZONE, J.A. Funções de resposta do feijoeiro (Phaseolus vulgaris L.) ao uso de nitrogênio e lâmina de irrigação. Piracicaba, 1986. 133p. (Doutorado Escola Superior de Agricultura "Luiz de Queiroz" / USP).

FRIZZONE, J.A. Programação matemática aplicada a projetos hidroagrícolas. In: CONGRESSO BRASILEIRO DE ENGENHARIA AGRÍCOLA, 24, Viçosa, 1995. Mini-Curso No. 95-3. Viçosa, SBEA/UFV, 1995. 29p. 
FUENTES, H. de. Consideraciones acerca de la producción y tratamiento de semillas de melon. In: SEMINÁRIO DE OLERICULTURA, 15., Viçosa, 1988. Viçosa, U.F.V., 1988. p.58-73.

GENUCHTEN, M. Th. A closed form equation for predicting the hydraulic conductivity of insaturated soils. Soil Science Society American Journal, 41:892-8, 1980.

GOLDBERG, D.; GORNAT, B.; RIMON, D. Drip irrigation: principles, design and agricultural practices. Kfar Shumaryahu, Drip Irrigation Scientific Publ., 1976. 296p.

GOMES, RP. Fruticultura brasileira. 3. ed., São Paulo, Nobel, 1977. 448p.

GRATTAN, S.R.; SHENNAN, C.; MAY, D.M.; MITCHELL, J.P.; BURAU, RG. Use of drainage water for irrigation of melons and tomatos. California Agriculture, Davis, 41(9/10):27-8, 1987.

HAGAN, RM \& STEWART, J.I. Water deficits - imgation design and programming. Journal of the Irrigation and Drainage Division. ASCE, New York, 98(2):215-237, 1972.

HART, W.E.; NORUM, D.I.; PERI, G. Optimal seasonal inigation application analysis. Journal of the Irrigation and Drainage Division. ASCE, New York, 106(3):221-235, 1980.

HERNANDEZ, F.B.T.; LEMOS FILHO, M.AF.; BUZETTI, S. Software HIDRISA e o balanço hídrico de Ilha Solteira. Iha Solteira, UNESP / 
FEIS / Área de Hidráulica e Imigação, 1995. 45p. (UNESP / FEIS / Área de Hidráulica e Imigação. Série Imigação, 1).

HSIAO, T.C. Plant response to water stress. Annual Review of Plant Physiology, Palo Alto, 24:519-70, 1973.

ISLAM, T.; SARKER, H.; ALAM, J.; RASHID, H. Water use and yield relationships of imigated potato. Agricultural Water Management, Amsterdam, 18:173-179, 1990.

INSTITUTO ADOLFO LUTZ. Normas analíticas do Instituto Adolfo Lutz Métodos químicos e físicos para análise de alimentos. 3. ed., São Paulo, Secretaria da Saúde do Estado de São Paulo, 1985. v. 1, 533p.

KRAMER, P.J. Plant and soil water relationship: a modem synthesis. New York, Mc-Graw Hill, 1969. 482p.

MACGILLIVRAY, J.H. Effects of imigation on the production of cantaloupes.

Proceedings of the American Society for Horticultural Science, Geneva, 57:266-72, 1951.

MAROUELLI, W.A.; SILVA, W.L.C.; SILVA, H.R Manejo da irrigação em hortaliças. Brasília, EMBRAPA/CNPH, 1994. 60p.

MARTIN, D.L.; WATTS, D.G.; GILLEY, J.R Model and production for imigation management. Journal of Irrigation and Drainage Engineering, New York, 110(2):149-64, 1984.

MEDINA SAN JUAN, S.H. Riego por goteo: teoria y prática. 2a ed., Madri, Mundi Prensa, 1985. 216p. 
MELO, A.M.T.; NAGAI, H.; TRANI, P.E. Melão. In: FAHL, et al. ed. Instruções agrícolas para o Estado de São Paulo. 6. ed, Campinas, IAC, 1995. (IAC. Boletim, 200. Versão eletrônica).

MENDLINGER, S. Effect of increasing plant density and salinity on yield and fruit quality in muskmelon. Scientia Horticultural, Amsterdam, 57(1/2):41-9, 1984.

MENDLINGER,S., FOSSEN, M. Flowering, vegetative growth, yield, and fruit quality in muskmelons under saline conditions. Journal of the American Society for Horticultural Science, Geneva, 118(6):868-72, 1993.

MENDLINGER, S. \& PASTERNAK, D. Effect of time of salinization on flowering, yield and fruit quality factors in melon (Cucumis melo L.). Journal of Horticultural Science, Ashford, 67(4):529-34, 1992a.

MENDLINGER, S. \& PASTERNAK, D. Screening for tolerance in melons. Hortscience, St. Joseph, 27(8):905-7, $1992 \mathrm{~b}$.

MILLAR, A.A. \& CHOUDHURY, E.N. A model to define operational irrigation frequency for maximum yield of crops. Turrialba, 30(4):39198, 1980.

MILLAR, A.A Manejo racional da irrigação: uso de informações básicas sobre diferentes culturas. Brasília, IICA, 1984. 57p. (IICA, Série Publicações Miscelâneas, 461) 
MIZRAHI, Y. \& PASTERNAK, D. Effect of salinity on quality of various agricultural crops. Plant and Soil, The Hague, 89(1/3):301-7, 1985.

OLITTA, AF.L.; ABREU, T.A; MARCHETTI, D.AB. Estudo comparativo dos métodos de imigação por sulcos e gotejo na cultura do melão. O Solo, Piracicaba, 70(2):7-14, 1978.

PALACIOS, E.V. Response functions of crops yield to soil moisture stress. Water Resources Bulletin, 17(4):699-703, 1981.

PAULINO, H.B.; TARSITANO, MA.A; HERNANDEZ, F.B.T.; BUZETTI, S. Viabilidade econômica da cultura do melão (Cucumis melo L.) na região de ITha Solteira - SP. Scientia Agricola, Piracicaba, 51(2):197-202, 1994.

PHENE,C.J.; DAVIS, K.R.; McCORMICK, RL.; PINCOT, A; WEEK, D.W. Evapotranspiration and irrigation scheduling of drip imigated cantaloupes. St. Joseph, ASAE, Paper n. 87-2526, 1987. 13p.

PIZARRO, F.C. Riegos localizados de alta frecuencia: goteo, microaspersion, exudacion. 2a ed, Madrid, Mundi Prensa, 1990.471p.

RADULOVICH, RA. AQUA, a model to evaluate water deficits and excesses in tropical cropping. Part II. Regional yield prediction. Agricultural and Forest Meteorology, Amsterdam, 52(3-4):253-261, 1990.

RAO, N.H.; SARMA, P.B.S.; CHANDER, S. Imigation scheduling under a limited water supply. Agricultural Water Management, Amsterdam, 15: 165-75, 1988. 
REICHARDT, K. Processos de transferência no sistema solo - planta atmosfera. Campinas, Fundação Cargill, 1985. 445p.

RITSCHEL, P. S.; SOUSA, V.F. da; CONCEIÇÃO, MA; SOUZA, V.A.B. de; COELHO, E.F. Efeito de época de suspesão da imigação na produtividade do meloeiro (Cucumis melo L.). In: Separata de CONGRESSO NACIONAL DE IRRIGAÇÃO E DRENAGEM, 10., Salvador, 1994. 10p. (No prelo).

SHMUELI, M \& GOLDBERG, D. Sprinkle, furrow and trickle irrigation of muskmelon in an arid zone. Hortscience, St. Joseph, 6(6):557-9, 1971.

SOUZA, V.F. de. Freqüência de aplicação de $\mathrm{N}$ e K via irrigação por gotejamento no meloeiro (Cucumis melo L. cv. Eldorado 300) em solo de textura arenosa. Botucatu, 1993. 131p. (Mestrado - Faculdade de Ciências Agronômicas / UNESP).

STEWART, J.I. \& HAGAN, RM Functions to predict effects of crop water deficits. Journal of the Irrigation and Drainage Division. ASCE, New York, 99(4):421-39, 1973.

TAYLOR, H.M \& ARKIN, G.F. Root modification: fundamentals and altematives. In: ARKIN, G.F. \& TAYLOR, H.M, ed., Modifying the root enviroment to reduce crop stress. Madison, ASAE , 1981. 407p. (ASAE, Monograph, 4)

TYLER, KB. \& LORENZ, O.A Nutrient absorption and growth of four muskmelon varieties. Proceedings of the American Society for Horticultural Science, Geneva, 84:364-71, 1964. 
VIEIRA, G. Índice de maturaçao para melão (Cucumis melo L.). In: SEMINÁRIO DE OLERICULTURA，10, Viçosa, 1984. Viçosa, UFV,1984. p. 48-67.

YAMAGUCHI, M; HUGHES, D.L.; YABUMOTO, K., JENNINGS, W.G.

Quality of cantaloup muskmelons variability and atribuites. Scientia Horticultural, Amsterdam, 6(1):59-70, 1977.

ZONTA, E.P. \& MACHADO, A.A SANEST - Sistema de análise estatística para microcomputadores. 1991. 120p. 
ANEXOS 


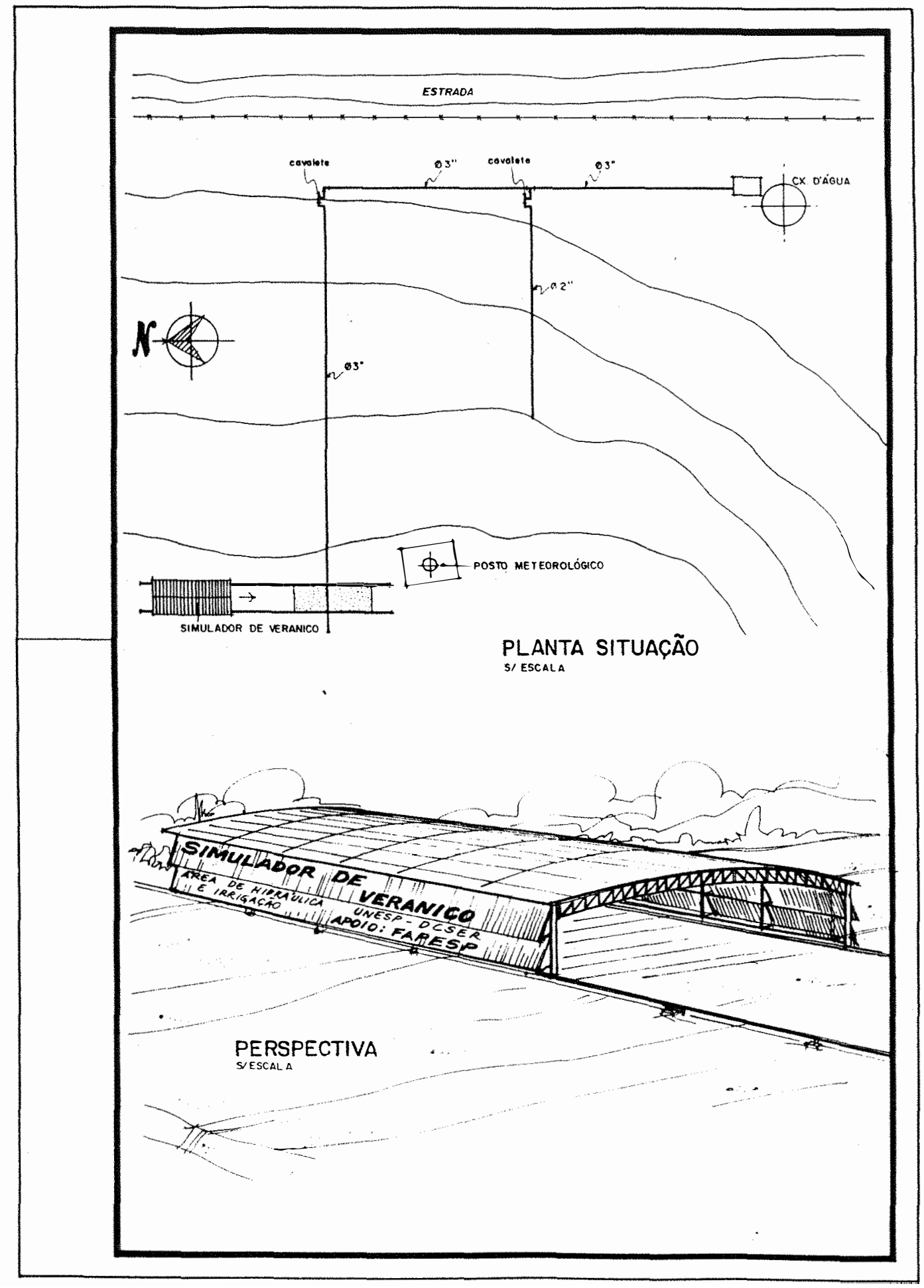




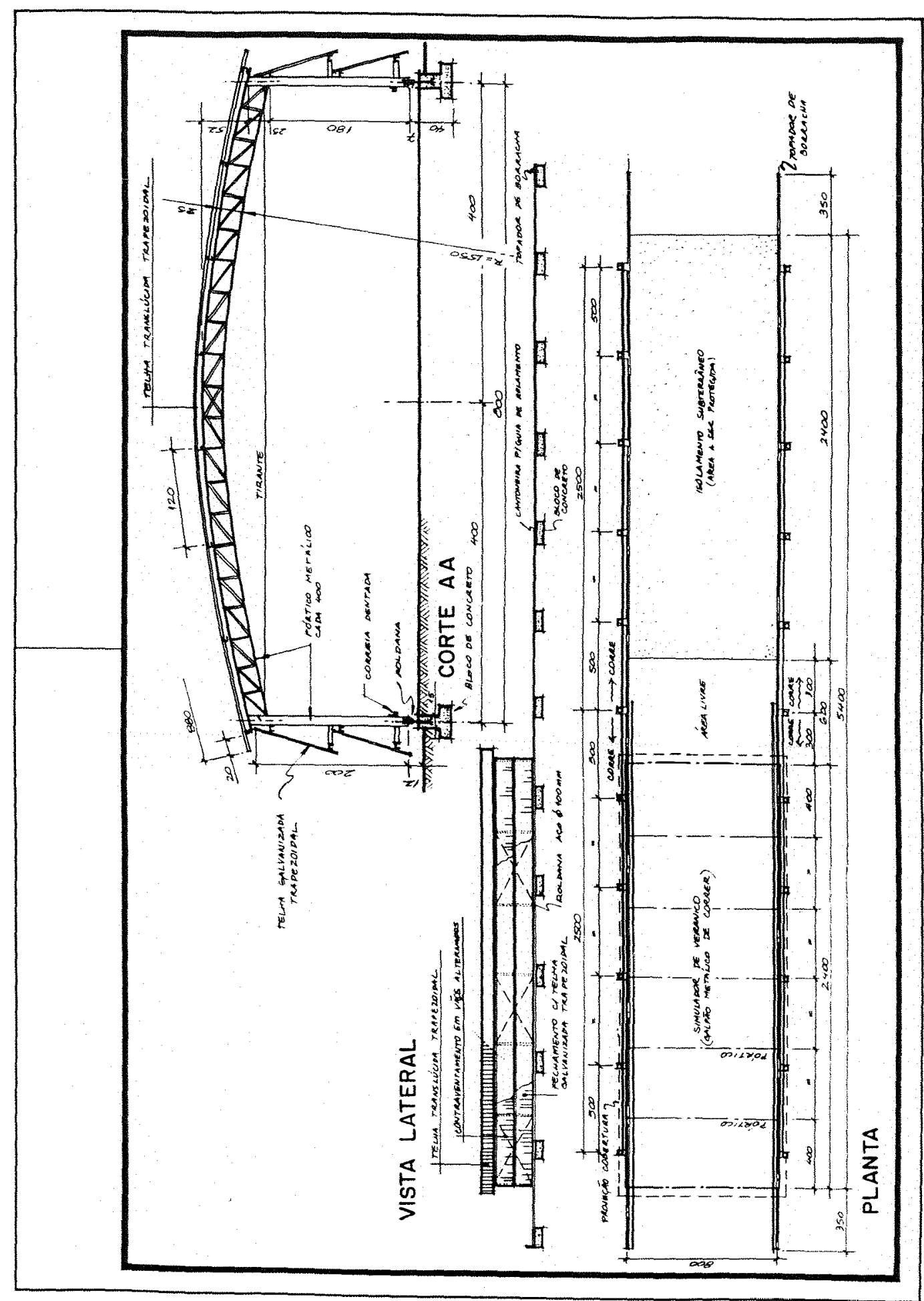




\section{PARÂMETROS CLIMÁTICOS OCORRIDOS DURANTE O EXPERIMENTO}

\begin{tabular}{|c|c|c|c|c|c|}
\hline$\overline{\text { DATA }}$ & $\begin{array}{c}\text { Temperatura Média } \\
(\text { o. C) }\end{array}$ & $\begin{array}{l}\text { UR } \\
(\%)\end{array}$ & $\begin{array}{c}\text { INS } \\
\text { (horas) }\end{array}$ & $\begin{array}{l}\text { ETPCA } \\
\text { (mm/dia) }\end{array}$ & $\begin{array}{l}\text { Chuva } \\
\text { (mm) }\end{array}$ \\
\hline 13/ago/95 & 24,6 & 35,3 & 8,7 & 4,4 & \\
\hline 14/ago/95 & 24,6 & 33,4 & 10,2 & 5,1 & \\
\hline 15/ago/95 & 22,9 & 32,7 & 10,9 & 3,5 & \\
\hline 16/ago/95 & 23,1 & 35,4 & 11,0 & 3,4 & \\
\hline 17/ago/95 & 22,9 & 31,3 & 10,1 & 5,8 & \\
\hline 18/ago/95 & 21,7 & 30,5 & 10,5 & 3,5 & \\
\hline 19/ago/95 & 24,4 & 26,4 & 10,9 & 4,3 & \\
\hline 20/ago/95 & 25,6 & 26,5 & 11,0 & 6,7 & \\
\hline 21/ago/95 & 24,4 & 24,4 & 10,8 & 4,8 & \\
\hline 22/ago/95 & 25,4 & 24,0 & 10,9 & 4,0 & \\
\hline 23/ago/95 & 29,4 & 28,1 & 10,4 & 5,0 & \\
\hline 24/ago/95 & 27,4 & 24,6 & 10,1 & 3,4 & \\
\hline 25/ago/95 & 25,6 & 32,4 & 10,1 & 3,7 & \\
\hline 26/ago/95 & 27,4 & 30,7 & 10,0 & 5,3 & \\
\hline 27/ago/95 & 27,7 & 24,2 & 10,1 & 4,2 & \\
\hline 28/ago/95 & 28,5 & 29,5 & 10,3 & 6,1 & \\
\hline 29/ago/95 & 26,1 & 22,9 & 10,5 & 5,5 & \\
\hline 30/ago/95 & 25,6 & 23,7 & 10,2 & 6,8 & \\
\hline 31/ago/95 & 29,6 & 19,1 & 10,4 & 5,6 & \\
\hline $01 /$ set $/ 95$ & 30,1 & 20,7 & 10,1 & 5,9 & \\
\hline $02 / \mathrm{set} / 95$ & 24,1 & 66,6 & 0,0 & 4,7 & \\
\hline $03 /$ set $/ 95$ & 19,9 & 42,1 & 8,9 & 3,7 & \\
\hline $04 /$ set/95 & 24,2 & 41,4 & 8,3 & 4,3 & \\
\hline $05 /$ set/95 & 25,4 & 32,8 & 9,8 & 3,1 & \\
\hline $06 /$ set $/ 95$ & 28,6 & 24,3 & 10,2 & 7,2 & \\
\hline $07 /$ set $/ 95$ & 27,4 & 18,1 & 10,2 & 6,1 & \\
\hline $08 /$ set/95 & 25,9 & 31,2 & 9,5 & 3,6 & \\
\hline $09 /$ set/95 & 22,6 & 38,0 & 9,6 & 3,3 & \\
\hline $10 /$ set/95 & 22,6 & 39,6 & 10,3 & 5,7 & \\
\hline $11 /$ set/95 & 25,6 & 27,3 & 11,1 & 4,3 & \\
\hline $12 /$ set/95 & 29,4 & 16,9 & 10,5 & 7,1 & \\
\hline 13/set/95 & 29,9 & 20,6 & 9,6 & 6,7 & \\
\hline $14 /$ set $/ 95$ & 30,9 & 36,5 & 8,6 & 6,9 & \\
\hline $15 /$ set/95 & 24,1 & 82,7 & 0,0 & 3,4 & 1,7 \\
\hline $16 /$ set/95 & 21,6 & 70,6 & 0,0 & 1,2 & 3,5 \\
\hline $17 /$ set/95 & 23,4 & 76,0 & 0,0 & 3,2 & \\
\hline $18 /$ set/95 & 27,1 & 41,2 & 8,0 & 4,3 & \\
\hline $19 /$ set/95 & 29,1 & 29,7 & 10,4 & 5,7 & \\
\hline $20 /$ set/95 & 30,1 & 26,9 & 10,8 & 5,5 & \\
\hline $21 /$ set $/ 95$ & 29,6 & 21,2 & 11,0 & 6,1 & \\
\hline
\end{tabular}




\begin{tabular}{|c|c|c|c|c|c|}
\hline DATA & $\begin{array}{c}\text { Temperatura Média } \\
\text { (o. C) }\end{array}$ & $\begin{array}{l}\text { UR } \\
(\%)\end{array}$ & $\begin{array}{c}\text { INS } \\
\text { (horas) }\end{array}$ & $\begin{array}{c}\text { ETPCA } \\
(\mathrm{mm} / \mathrm{dia})\end{array}$ & $\begin{array}{l}\text { Chuva } \\
\text { (mm) }\end{array}$ \\
\hline $22 / \mathrm{set} / 95$ & 29,4 & 19,4 & 11,0 & 7,2 & \\
\hline $23 /$ set $/ 95$ & 30,1 & 20,2 & 11,0 & 7,3 & \\
\hline $24 /$ set/95 & 31,6 & 15,3 & 10,6 & 8,4 & \\
\hline $25 /$ set $/ 95$ & 31,4 & 25,5 & 5,2 & 4,9 & \\
\hline $26 /$ set/95 & 31,1 & 43,2 & 8,5 & 4,2 & \\
\hline $27 / \mathrm{set} / 95$ & 27,9 & 40,9 & 8,7 & 7,0 & \\
\hline $28 / \mathrm{set} / 95$ & 25,9 & 38,0 & 10,6 & 5,4 & \\
\hline $29 /$ set/95 & 28,9 & 35,0 & 8,5 & 6,1 & \\
\hline $30 /$ set/95 & 27,6 & 59,9 & 0,5 & 3,6 & \\
\hline 01/out/95 & 27,4 & 50,6 & 4,4 & 2,6 & \\
\hline 02/out/95 & 28,9 & 53,2 & 7,5 & 3,2 & 14,8 \\
\hline 03/out/95 & 24,8 & 88,0 & 0,1 & 2,1 & 3 \\
\hline 04/out/95 & 26,1 & 44,6 & 10,2 & 3,4 & 0,6 \\
\hline 05/out/95 & 25,6 & 36,3 & 10,5 & 5,9 & \\
\hline 06/out/95 & 26,9 & 43,9 & 10,7 & 3,0 & \\
\hline 07/out/95 & 27,9 & 43,9 & 10,8 & 6,2 & \\
\hline 08/out/95 & 28,1 & 29,0 & 11,2 & 5,5 & \\
\hline 09/out/95 & 28,6 & 19,7 & 11,3 & 7,0 & \\
\hline 10/out/95 & 29,6 & 20,2 & 11,2 & 6,0 & \\
\hline 11/out/95 & 31,1 & 19,3 & 11,1 & 7,1 & \\
\hline 12/out/95 & 30,1 & 28,1 & 10,7 & 7,9 & \\
\hline 13/out/95 & 34,4 & 37,3 & 9,3 & 8,2 & \\
\hline 14/out/95 & 27,9 & 46,2 & 7,6 & 3,7 & \\
\hline 15/out/95 & 29,6 & 33,5 & 10,7 & 4,9 & \\
\hline 16/out/95 & 28,6 & 50,1 & 2,5 & 4,2 & \\
\hline 17/out/95 & 32,3 & 42,7 & 8,7 & 4,2 & \\
\hline 18/out/95 & 30,3 & 41,2 & 5,1 & 4,4 & \\
\hline 19/out/95 & 30,9 & 34,5 & 10,2 & 6,5 & \\
\hline 20/out/95 & 30,4 & 44,5 & 2,3 & 4,8 & \\
\hline 21/out/95 & 30,4 & 37,4 & 7,9 & 5,9 & \\
\hline 22/out/95 & 26,6 & 74,7 & 3,4 & 4,0 & 2,2 \\
\hline 23/out/95 & 29,1 & 48,8 & 8,7 & 4,1 & \\
\hline 24/out/95 & 30,4 & 41,6 & 8,1 & 4,7 & \\
\hline 25/out/95 & 28,6 & 74,9 & 3,2 & 7,3 & 33,5 \\
\hline 26/out/95 & 28,6 & 76,6 & 5,2 & 3,4 & 0,8 \\
\hline 27/out/95 & 26,6 & 87,2 & 2,0 & 4,6 & 21,1 \\
\hline 28/out/95 & 27,6 & 66,7 & 7,0 & 2,9 & \\
\hline 29/out/95 & 24,9 & 83,0 & 0,2 & 2,7 & 1,5 \\
\hline 30/out/95 & 24,4 & 60,2 & 8,3 & 4,7 & 10 \\
\hline 31/out/95 & 27,9 & 73,1 & 8,1 & 5,6 & \\
\hline 01/nov/95 & 28,6 & 75,8 & 7,7 & 5,0 & 0,4 \\
\hline 02/nov/95 & 28,1 & 62,0 & 9,1 & 4,9 & \\
\hline
\end{tabular}




\begin{tabular}{|c|c|c|c|c|c|}
\hline$\overline{\text { DATA }}$ & $\begin{array}{c}\text { Temperatura Média } \\
(\text { (o. C })\end{array}$ & $\begin{array}{l}\text { UR } \\
(\%)\end{array}$ & $\begin{array}{c}\text { DNS } \\
\text { (horas) }\end{array}$ & $\begin{array}{c}\text { ETPCA } \\
(\mathrm{mm} / \mathrm{dia})\end{array}$ & $\begin{array}{c}\text { Chuva } \\
(\mathrm{mm})\end{array}$ \\
\hline $03 /$ nov/95 & 30,6 & 44,7 & 10,8 & 4,1 & \\
\hline 04/nov/95 & 31,9 & 36,4 & 10,3 & 5,6 & \\
\hline 05/nov/95 & 30,1 & 56,2 & 7,7 & 5,8 & 1,6 \\
\hline 06/nov/95 & 28,6 & 45,0 & 10,5 & 5,6 & \\
\hline 07/nov/95 & 31,1 & 39,7 & 10,5 & 5,2 & \\
\hline 08/nov/95 & 31,9 & 39,1 & 10,3 & 5,2 & \\
\hline 09/nov/95 & 26,9 & 70,5 & 2,9 & 6,1 & 5,2 \\
\hline 10/nov/95 & 30,9 & 45,3 & 11,3 & 5,0 & \\
\hline 11/nov/95 & 31,9 & 46,5 & 11,0 & 6,8 & \\
\hline $12 /$ nov/95 & 30,6 & 46,2 & 6,9 & 5,0 & \\
\hline $13 /$ nov/95 & 29,9 & 56,0 & 2,0 & 4,5 & \\
\hline $14 /$ nov/95 & 29,9 & 58,8 & 6,5 & 4,7 & \\
\hline 15/nov/95 & 29,4 & 54,2 & 7,4 & 4,0 & \\
\hline $16 /$ nov/95 & 28,9 & 54,3 & 8,6 & 7,6 & \\
\hline 17/nov/95 & 28,7 & 70,1 & 5,5 & 12,3 & 32,2 \\
\hline $18 /$ nov/95 & 26,6 & 90,7 & 2,5 & 4,0 & 26,6 \\
\hline 19/nov/95 & 23,9 & 80,4 & 0,0 & 3,0 & 71,2 \\
\hline 20/nov/95 & 23,6 & 53,9 & 11,1 & 4,8 & \\
\hline 21/nov/95 & 25,8 & 41,9 & 12,4 & 5,2 & \\
\hline $22 /$ nov/95 & 23,6 & 46,8 & 12,5 & 6,3 & \\
\hline 23/nov/95 & 24,9 & 52,0 & 10,1 & 5,3 & \\
\hline $24 /$ nov/95 & 25,9 & 45,2 & 11,7 & 6,1 & \\
\hline $25 /$ nov/95 & 24,9 & 51,9 & 11,5 & 6,2 & \\
\hline 26/nov/95 & 27,6 & 52,9 & 8,2 & 5,3 & \\
\hline 27/nov/95 & 25,4 & 60,7 & 9,5 & 5,0 & 15,4 \\
\hline 28/nov/95 & 26,1 & 53,7 & 9,5 & 4,1 & 42,2 \\
\hline $29 /$ nov/95 & 23,6 & 71,6 & 3,9 & 4,8 & 8,2 \\
\hline
\end{tabular}

